\title{
Laurel Wilt in Natural and Agricultural Ecosystems: Understanding the Drivers and Scales of Complex Pathosystems
}

\author{
Randy C. Ploetz ${ }^{1, *}$, Paul E. Kendra ${ }^{2}$, Robin Alan Choudhury ${ }^{3}$, Jeffrey A. Rollins ${ }^{3}$, \\ Alina Campbell ${ }^{2}$, Karen Garrett ${ }^{3}$, Marc Hughes ${ }^{4}$ and Tyler Dreaden ${ }^{5}$ \\ 1 Tropical Research \& Education Center, University of Florida, 18905 SW 280th Street, Homestead, \\ FL 33031-3314, USA \\ 2 USDA-ARS Subtropical Horticulture Research Station, Miami, FL 33158-1857, USA; \\ paul.kendra@ars.usda.gov (P.E.K.); Alina.Campbell@ars.usda.gov (A.C.) \\ 3 Plant Pathology Department, University of Florida, Gainesville, FL 32611, USA; \\ ra.choudhury@ufl.edu (R.A.C.); rollinsj@ufl.edu (J.A.R.); karengarrett@ufl.edu (K.G.) \\ 4 College of Tropical Agriculture and Human Resources, University of Hawaii at Manoa, \\ 875 Komohana Street, Hilo, HI 96720, USA; Mhughes7@hawaii.edu \\ 5 Forest Health Research and Education Center, Southern Research Station, USDA-Forest Service, Lexington, \\ KY 40546, USA; tdreaden@fs.fed.us \\ * Correspondence: kelly12@ufl.edu; Tel.: +1-786-217-9278
}

Academic Editors: Matteo Garbelotto and Paolo Gonthier

Received: 22 December 2016; Accepted: 13 February 2017; Published: 18 February 2017

\begin{abstract}
Laurel wilt kills members of the Lauraceae plant family in the southeastern United States. It is caused by Raffaelea lauricola T.C. Harr., Fraedrich and Aghayeva, a nutritional fungal symbiont of an invasive Asian ambrosia beetle, Xyleborus glabratus Eichhoff, which was detected in Port Wentworth, Georgia, in 2002. The beetle is the primary vector of $R$. lauricola in forests along the southeastern coastal plain of the United States, but other ambrosia beetle species that obtained the pathogen after the initial introduction may play a role in the avocado (Persea americana Miller) pathosystem. Susceptible taxa are naïve (new-encounter) hosts that originated outside Asia. In the southeastern United States, over 300 million trees of redbay (P. borbonia (L.) Spreng.) have been lost, and other North American endemics, non-Asian ornamentals and avocado-an important crop that originated in MesoAmerica-are also affected. However, there are no reports of laurel wilt on the significant number of lauraceous endemics that occur in the Asian homeland of R. lauricola and $X$. glabratus; coevolved resistance to the disease in the region has been hypothesized. The rapid spread of laurel wilt in the United States is due to an efficient vector, X. glabratus, and the movement of wood infested with the insect and pathogen. These factors, the absence of fully resistant genotypes, and the paucity of effective control measures severely constrain the disease's management in forest ecosystems and avocado production areas.
\end{abstract}

Keywords: laurel wilt; Lauraceae; redbay; avocado; Raffaelea lauricola; Xyleborus glabratus; ambrosia beetles; coevolution

\section{Introduction}

New diseases are developing at an alarming rate on the world's trees. Diverse forest communities, pulp and timber plantations, and agricultural production are impacted in tropical, temperate and boreal environments [1-4]. Host jumps, pathogen hybridization and climate change have been associated with some of the new diseases [5-8], but other outbreaks have resulted from the invasion of naïve 
ecosystems by exotic pathogens [9-12]. The occasionally catastrophic responses of new-encounter hosts to alien pathogens are poorly understood, unpredictable and warrant further study [1].

In 2004, stands of redbay, Persea borbonia (L.) Spreng., began to die on Hilton Head Island, South Carolina, United States [13] (Figure 1A). At the time, the problem was not widespread, and abiotic factors, such as drought or salt-water damage, were invoked as possible causes for losses of this native tree. However, as the problem spread a new disease, laurel wilt, was recognized [13].

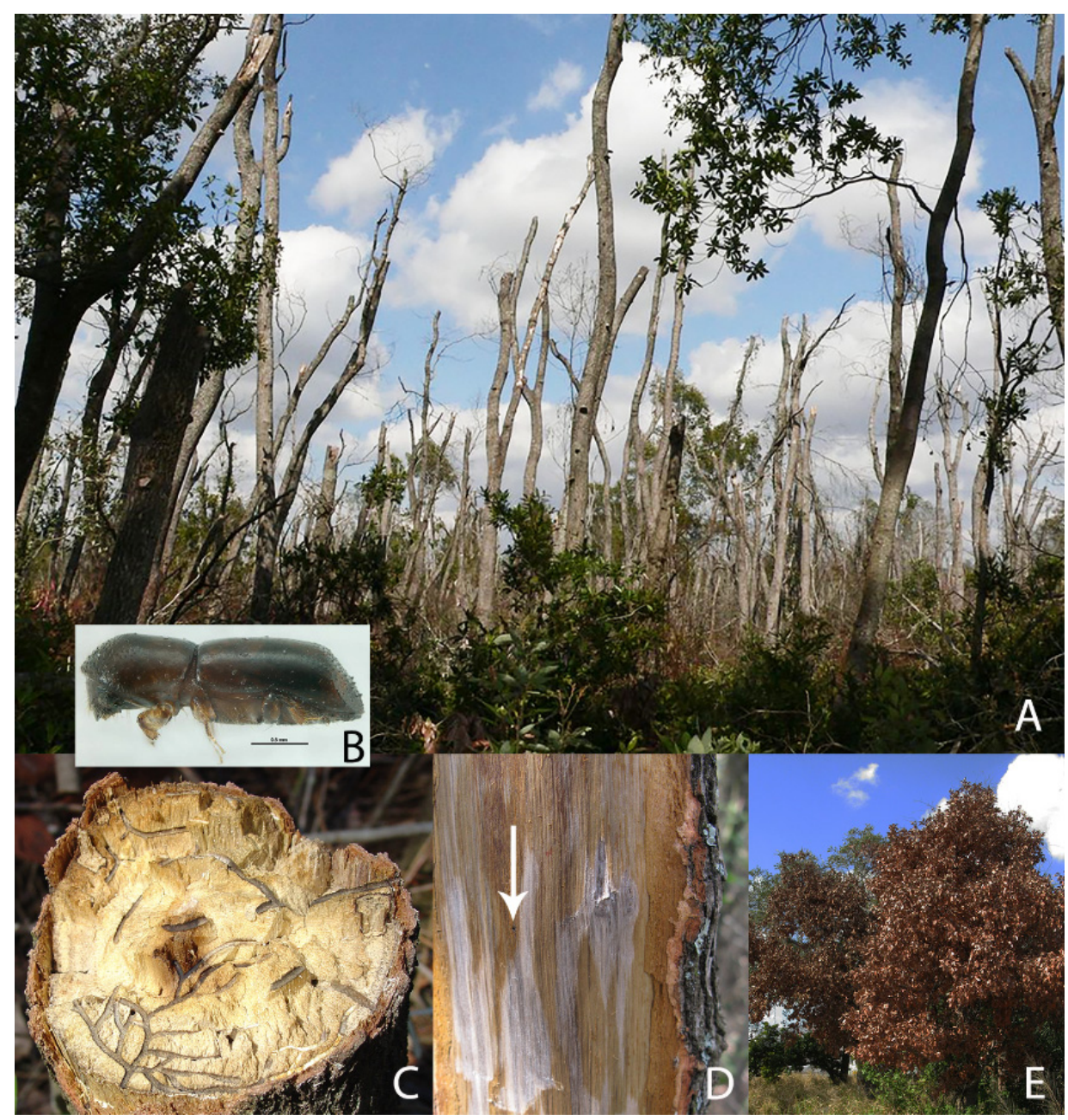

Figure 1. (A) Devastation caused by laurel wilt in a former stand of redbay, Persea borbonia, in Georgia in 2009 (photo: R. Ploetz). (B) Adult female of Xyleborus glabratus (PaDIL photo 33462, Justin Bartlett, http://www.padil.gov.au/). (C) Galleries of X. glabratus in a redbay tree that was killed by laurel wilt (photo: P. Kendra). (D) Internal staining of the sapwood of a redbay tree that is affected by laurel wilt (photo: R. Ploetz). Note inconspicuous entrance to a gallery of X. glabratus denoted with an arrow. During the early development of this disease, evidence for X. glabratus is limited. (E) Laurel wilt-induced death of redbay trees in Florida (photo: R. Ploetz). Laurel wilt-affected trees of native Persea spp. in the southeastern United States defoliate, as in A), only several months after dying.

Laurel wilt affects trees and shrubs in the Lauraceae (Laurales, Magnoliid complex). It is caused by a fungal symbiont, Raffaelea lauricola T.C. Harr., Fraedrich and Aghayeva (Ophiostomatales), of an invasive Asian ambrosia beetle, Xyleborus glabratus Eichhoff (Curculionidae: Scolytinae) [13] (Figure 1B,C). Starting in its putative epicenter of Port Wentworth, Georgia, United States (i.e., where X. glabratus was first detected in 2002) [14,15], the disease had spread by August 2016 as far west as $95^{\circ} \mathrm{W}$, as far east as $78.5^{\circ} \mathrm{W}$, as far north as $35^{\circ} \mathrm{N}$ and as far south as $25.5^{\circ} \mathrm{N}$ [16]. 
An estimated 300 million redbay trees have been killed by laurel wilt [17], and damage to the ecosystems that are associated with this important species has been documented or predicted [18-23]. Other common species in the southeastern United States, such as sassafras (Sassafras albidum (Nutt.) Nees), silk bay (P. humilis Nash), and swamp bay (P. palustris (Raf.) Sarg.), are decimated by the disease, as are threatened (pondspice, Litsea aestivalis (L.) Fernald) and endangered endemics (pondberry, Lindera melissifolia (Walter) Blume) [24-26]. Commercial production of a crop from MesoAmerica, avocado (P. americana Miller), was affected in Florida beginning in 2012, and that outbreak poses an increasingly serious threat to commercial production there and in other, currently unaffected areas $[27,28]$. Other lauraceous species from Europe and the United States are also susceptible, including bay laurel (Laurus nobilis L.) and, after artificial inoculation, California laurel (Umbellularia californica (Hook. and Arn.) Nutt.), gulf licaria (Licaria triandra (Sw.) Kosterm.), lancewood (Nectandra coriacea (Sw.) Griseb.), Northern spicebush (Lindera benzoin (L.) Blume) and Viñátigo (P. indica (L.) Spreng.) [13,26,29-32]. An Asian endemic, camphortree (Cinnamomum camphora (L.) J. Presl.), generally tolerates the disease [33].

\section{Origins}

Rabaglia et al. [15] indicated that X. glabratus was native to Asia and had been recorded from Bangladesh, India, Japan, Myanmar and Taiwan. Recently, Hulcr and Lou [34] reported the insect in mainland China. They confirmed that X. glabratus preferred lauraceous hosts (Phoebe zhennan S. Lee and F.N. Wei, Machilus nanmu Nees, C. camphora and Phoebe neurantha (Hemsl.) Gamble in China), and that taxa in other families were rarely colonized (only two of 40 collections).

Harrington et al. [35] recovered R. lauricola from specimens of X. glabratus from Japan and Taiwan. Since there are no reports of laurel wilt in the United States prior to 2004, X. glabratus probably carried the pathogen when it was first detected in Port Wentworth $[14,15]$. The focal and temporal spread of laurel wilt from that area (see [16]) and the genetically uniform populations of $R$. lauricola and $X$. glabratus that are found throughout the southeastern United States suggest that a single founding event, in or before 2002, may be responsible for the laurel wilt epidemic [17,36,37].

Non-Asian suscepts in the Lauraceae are all naïve (new-encounter) hosts $[1,26]$. Despite the wide geographic range of $X$. glabratus and the large number of species in the Lauraceae that are endemic to Asia (see below), there is only one report of laurel wilt in Asia, and that was on the introduced non-Asian host, avocado [38]. Fraedrich et al. [33] indicated that "there are no reports that indicate R. lauricola causes a plant disease in Asia", and Hulcr and Lou [34] doubted that (sic) "X. glabratus displays tree-killing behavior in its native range." If laurel wilt occurs in Asia on Asian members of the Lauraceae, it must be inconspicuous.

\section{Coevolution}

The term "coevolution" was coined to describe butterfly x plant interactions [39]. However, the idea that reciprocal evolution occurred between sympatric species was discussed by Darwin [40] and described in a plant-pathological context in the 1950s. In describing results from his classic research on flax rust, Flor [41] suggested that " ... obligate parasites, such as the rust fungi, must have evolved in association with their hosts" and that "... during their parallel evolution, host and parasite developed complementary genic systems". Gene-for-gene and genetically quantitative/multi-gene systems have now been identified in many other pathosystems, and the specific adaptation of pathogens to host taxa, such as those described as formae speciales, is generally accepted as "the outcome of coevolution" [42]. These relationships can be conceived of as arms races in which increased disease resistance develops in a host in response to increased virulence in a pathogen [43,44].

Although these interactions can be difficult to document $[43,45,46]$, coevolution appears to be an important factor in the development of many pathosystems [47]. Several criteria can be used to identify possible coevolved pathosystems [41-43,45,46,48-52]; they include: 
1. A limited, often specific host range for the pathogen;

2. An original geographic distribution of the pathogen that overlaps with that of the host;

3. The occurrence of significant disease resistance in the host's primary center of origin;

4. Regional overlap of resistance and pathogenicity factors and phenotypes in the respective host and pathogen populations (i.e., geographic evidence for reciprocal selection);

5. Gene-for-gene relationships (although quantitative, non-gene-for-gene interactions can also co-evolve); and

6. Tandem speciation (also known as parallel cladogenesis).

Due to the rigorous criteria that are needed to confirm these relationships, it is not surprising that relatively few unequivocal examples of host $x$ pathogen coevolution exist [51,52]. Most proposed coevolved pathosystems possess some, but not all, of the above attributes $[10,42,53,54]$. For example, although the first three of the above criteria are met for $R$. lauricola in Asia, there are no data for criteria 4-6. Future work may provide additional support for the idea that $R$. lauricola coevolved with endemic laurels in Asia. In the meantime, studies of Asian species in the Lauraceae, such as camphortree, could provide valuable insight into how tolerant hosts respond to this pathogen, and which attributes should be sought during the development of laurel wilt-resistant genotypes.

\section{Ambrosial Symbioses}

Xyleborine ambrosia beetles (Curculionidae:Scolytinae:Xyleborini) exhibit a haplodiploid, sibling mating system, which is also known as arrhenotoky [55-57]. Females are diploid and establish colonies after dispersion to uncolonized portions of the same or new host trees. Fertilized females can establish new colonies of females and haploid males, whereas nonfertilized females lay haploid eggs that become males. Males are flightless and rarely leave their natal galleries [58], where they mate with their mother and sisters.

Ambrosia beetles carry their fungal symbionts in specialized structures called mycangia [59-61]. In the Xyleborini, paired pre-oral (also known as mandibular) mycangia are small invaginations at mandible bases, mesothoracic mycangia are single, large invaginations between the meso- and metanotum, and elytral mycangia are small cavities at elytra bases [61,62]. In the species that have been examined, only one type of mycangium is present. However, mycangia are absent in some species that plunder fungal gardens of other species [63].

When adult females disperse to new trees, they bore brood galleries into host tree xylem, in which they cultivate gardens of the fungal symbionts. The developing colony feeds on these fungi (not wood), and as the colony matures new females are eventually produced. They then perpetuate the species by dispersing and establishing new colonies. Although some ambrosia beetle species (e.g., Xylosandrus compactus Eichhoff) can attack and colonize (establish brood colonies in) healthy trees [64,65], most reproduce only in stressed or dead trees.

During the early stages of the laurel wilt epidemic, Fraedrich et al. $[13,33]$ examined X. glabratus $x$ redbay interactions. They indicated that initial attacks by the insect in healthy trees were aborted and that reproduction by the insect was not observed in such trees. Nonetheless, aborted attacks were sufficient to infect trees with $R$. lauricola. Only after laurel wilt began to develop in infected trees was brood development by X. glabratus observed [13,33]. If this sequence is typical, X. glabratus may resemble other ambrosia beetle species in that it preferentially colonizes and reproduces in compromised or dead trees.

Most ambrosia beetles are generalists with wide host ranges. Thus, X. glabratus is unusual as it displays a strong preference for trees in the Lauraceae. Sesquiterpenes, rather than ethanol, the stress metabolite to which ambrosia beetles are usually attracted, appear to be a significant component of the attraction signature of these trees [66]. This difference has been cited when indicating that the $X$. glabratus vector relationship is exceptional, but there appears to be no evidence that trees identified with these signatures then support colonization and brood development before disease develops. Thus, 
indications that the interaction of X. glabratus with its host trees is atypical $[61,67,68]$ should be clarified. Clearly, better information on, and a distinction between, the early (attack phase) and mid-stage interactions of $X$. glabratus with its host trees (colonization and brood development) are needed.

In discussing the appearance of laurel wilt in the United States and its absence in the Asian homeland of X. glabratus, Hulcr and Dunn [68] proposed that "the sudden emergence of pathogenicity" was due to "a new evolutionary phenomenon." A more parsimonious explanation for the emergence of laurel wilt is that coevolution with $R$. lauricola eliminated susceptible species in Asia, but not in the United States. The idea that American strains of $R$. lauricola became pathogenic after their move from Asia is not supported by data from studies that detected no differences in pathogenicity to avocado and swamp bay between isolates of $R$. lauricola from Asia and the United States [36,38]. Hulcr and Dunn [68] also suggested that an "olfactory mismatch" may be responsible for the identification by X. glabratus of nondiseased host trees as suitable for colonization. Since X. glabratus propagates in compromised host trees, as do other ambrosia beetle species, the attractive sesquiterpenes may simply enable X. glabratus to identify trees in which its ambrosial symbiont, R. lauricola, will establish, regardless of the host tree's health status. In summary, pathological differences have not been evident between R. lauricola in Asia and the United States, and X. glabratus and other ambrosia beetles appear to have similar reproductive preferences for compromised or dead trees. However, no other ambrosial symbiont is known to be a systemic, lethal pathogen. Even when ambrosial symbionts kill trees (e.g., R. quercus-mongolicae K.H. Kim, Y.J. Choi and H.D. Shin, R. quercivora Kubono and Shin. Ito, and Fusarium euwallaceae S. Freeman, Z. Mendel, T. Aoki et O'Donnell), mortality is due to localized (nonsystemic) necrosis and multiple attacks by the associated ambrosia beetle vectors [1].

More work is needed to understand the impact of $R$. lauricola on naïve American hosts. Host tree colonization by $X$. glabratus is incompletely understood, and discerning the role that other ambrosia beetle species may play in the laurel wilt epidemic has only begun. Several other species are associated with redbay, avocado and other lauraceous hosts, but they have been considered as vectors of $R$. lauricola only recently. The general absence of X. glabratus in avocado orchards that are affected by laurel wilt, the pathogen's presence in other species of ambrosia beetle that are recovered from avocado and other host trees, and the experimental demonstration of pathogen transmission and subsequent laurel wilt development in redbay and avocado suggest that species other than X. glabratus could play roles in the epidemiology of this disease $[1,69,70]$.

\section{Vectors of Raffaelea lauricola}

Although ambrosia beetles have an obligate association with nutritional fungi $[59,61,71,72]$, these can be promiscuous relationships wherein a given beetle species carries more than a single symbiont, and the same fungus species is present in more than one species of beetle. The movement of symbionts amongst ambrosia beetle species had been recognized previously $[69,71,73,74]$. However, the magnitude and speed with which this has occurred for R. lauricola is unprecedented [70]. Since its introduction into the United States in or before 2002, R. lauricola has been horizontally transferred from X. glabratus to nine additional ambrosia beetle species $[1,69,70,75,76]$.

Reared (from laurel wilt-affected host trees) or trapped individuals (in the proximity of laurel wilt-affected trees) of 14 species of ambrosia beetle (Ambrosiodmus, Euwallacea, Premnobius, Xyleborus, Xyleborinus and Xylosandrus spp.) were assayed for R. lauricola by Ploetz et al. [70]. During 10 experiments, the pathogen was recovered from 34\% (246 of 726) of the individuals that were associated with Persea spp. that are native to the southeastern United States, but only 6\% (58 of 931) of those that were associated with avocado. Raffaelea lauricola was recovered from 10 of the ambrosia beetle species that were assayed, including X. glabratus, but was most prevalent in Xyleborus congeners [70]. Previous reports had suggested that Raffaelea spp. were the primary symbionts of Xyleborus spp. [74,75]. In general, mycangia of X. glabratus contained 10-1000 times more colony forming units (CFUs) of $R$. lauricola than the other assayed species. From native Persea spp. and avocado, R. lauricola was recovered from a respective $91 \%$ and $60 \%$ of the live specimens of X. glabratus that were assayed [70]. 
Although little is known about symbioses that are established between $R$. lauricola and different ambrosia beetle species, some of these insects may be involved in the ongoing epidemic in the southeastern United States [28,70]. In no-choice experiments, Carrillo et al. [69] reported that six and two species other than X. glabratus transmitted R. lauricola to potted redbay and avocado trees, and that laurel wilt developed in six and one of these interactions, respectively.

Kostovcik et al. [74] indicated that different types of mycangia may "support functionally and taxonomically distinct" symbioses. In summarizing a study of microbial communities in mycangia of Xyleborus affinis Eichhoff, Xyleborus ferrugineus Fabricius and Xylosandrus crassiusculus Motschulsky, they concluded that the mandibular (pre-oral) mycangium found in Xyleborus enabled the establishment of a broader array of symbionts than the larger and more exposed mesonotal mycangium possessed by X. crassiusculus (and Xyleborinus saxesenii Ratzeburg).

Hulcr et al. [77] studied how different ambrosia beetle species responded to $R$. lauricola. In olfactometer assays, $X$. glabratus was significantly attracted to R. lauricola in 54 of 84 assays $(p=0.004)$. In contrast, adult females of X. saxesenii and X. crassiusculus were significantly repelled by the fungus [77], which corresponds with its uncommon recovery from these species $(1 \%-4 \%$ of all assayed individuals in [70]). Interestingly, another beetle that carried $R$. lauricola more frequently than X. saxesenii and X. crassiusculus, X. ferrugineus ( $11 \%-57 \%$ of the individuals in [70]), had a net nonresponse to the fungus; i.e., was repelled about as often (156 assays) as it was attracted (132 assays) $(p=0.16)$ [77].

Although beetle attraction to, or avoidance of, R. lauricola may impact whether it is a factor in the epidemiology of this disease [28,70], it is unclear whether species that are repelled by $R$. lauricola in olfactometers could still be occasional vectors of the pathogen and whether attracted or neutral species would disseminate the pathogen more frequently. Clearly, the involvement of other ambrosia beetle species in the laurel wilt epidemic requires more study. Nonetheless, we are beginning to understand the vector portion of this puzzle. By virtue of their affinity for Raffaelea spp. [70,74,75], species of Xyleborus might be expected to foster symbioses with $R$. lauricola more readily than species in other genera. In contrast, species with mesonotal mycangia, such as X. crassiusculus and X. saxesenii, should be able to carry greater quantities of the pathogen, based on the larger size of this organ compared to pre-oral mycangia. Even though they are infested with $R$. lauricola infrequently and are not attracted to the fungus in olfactometers, highly infested individuals with mesonotal mycangia could be vectors of R. lauricola.

\section{Vector Chemical Ecology and Host Location}

Host-based attractants (kairomones) have been studied most extensively for the primary vector of R. lauricola, dispersing females of X. glabratus. This beetle is not attracted to ethanol [78], the standard lure for ambrosia beetle detection [79]. The strongest female attractants identified to date are terpenoid kairomones, specifically volatile sesquiterpenes emitted from host wood [80-82]. In comparative studies with nine lauraceous species, emissions of four sesquiterpenes ( $\alpha$-copaene, $\alpha$-cubebene, $\alpha$-humulene, and calamenene) were positively correlated with in-flight attraction of X. glabratus, and electroantennography has confirmed olfactory chemoreception of these compounds [66]. A succession of field lures has been developed using essential oils naturally high in sesquiterpenes, including manuka oil (derived from Leptospermum scoparium J.R. Forst. and G. Forst., Myrtaceae; [80]), phoebe oil (Phoebe porosa (Nees and Martius) Barroso, Lauraceae; [80]), and cubeb oil (Piper cubeba L. f., Piperaceae; [83-86]). Laboratory bioassays with fractionated cubeb oil identified the negative enantiomer of $\alpha$-copaene as a primary attractant, sufficient to evoke positive chemotaxis. Currently, the most effective lure for X. glabratus is an essential oil product enriched to $50 \%(-)$ - $\alpha$-copaene content $[87,88]$.

Exiting the natal tree to locate and colonize new resources is critical for the reproductive success of ambrosia beetles, but this brief dispersal event potentially exposes them to predation and adverse environmental conditions. To minimize risks associated with dispersion, it would be adaptive for 
females to have efficient host-seeking behaviors, guided by reliable cues. Kendra et al. [66] proposed that host location and acceptance is a multistep process directed by a series of cues presented in sequential order.

Initiation of dispersal flight in scolytine beetles is determined by light intensity, temperature, relative humidity and other environmental cues ([89] and references therein). With X. glabratus, females engage in host-seeking flight during the late afternoon and early evening, several hours earlier than other species of Xyleborus in Florida [90]. While in flight, females orient initially toward long-range olfactory cues; $\alpha$-copaene appears to be the primary kairomone, but other terpenoids likely contribute to generate an attractive "signature bouquet" of the Lauraceae $[66,82,87]$. In addition to sesquiterpenes, several monoterpenes have been reported as kairomones, including eucalyptol (1,8 cineole) [91] and a blend of redbay leaf volatiles [92]. There is no evidence that X. glabratus utilizes sex or aggregation pheromones [78].

As females approach the focal source of host kairomones, visual cues assist in directing flight toward individual trees. Mayfield and Brownie [93] demonstrated that stem silhouette diameter aids in host location, but only when presented in an appropriate chemical context (i.e., presented concurrently with host odors). These experimental data support field observations that the oldest, largest-diameter trees are typically the first to be attacked by X. glabratus. In addition, there is a higher density of beetle entrance holes on the trunk and large diameter branches of redbay and swampbay, compared to smaller diameter branches $[10,58,84]$. In mature avocado trees, the highest emissions of $\alpha$-copaene and $\alpha$-cubebene are detected on the trunk and larger branches [94]. This chemical gradient may further assist with location of optimal sites for landing and initiation of a gallery. Even though large hosts are preferred, once those resources are depleted, smaller diameter trees are utilized, thereby enabling low populations of X. glabratus to persist for many years [95].

The short-range cues that prompt a shift from host-seeking to host acceptance and boring behaviors have received scant study. Knowledge in this area could facilitate the development of effective repellents or boring deterrents. Once a female makes contact with a potential host, she likely integrates a variety of stimuli, including olfactory, gustatory, contact chemosensory, tactile and visual cues, all of which must reinforce the message that an appropriate host has been found before a reproductive effort is initiated. In short-range laboratory bioassays, X. glabratus is attracted to volatiles emitted from its fungal symbiont [77], and in field tests these volatiles increased beetle captures when combined with host-based lures [96]. The ability to detect food-based odors may be adaptive in the host-choice process, confirming that the tree under evaluation is capable of supporting growth of required (nutritional) fungal resources.

\section{Pathogen Attributes}

The fungal symbionts of ambrosia beetles typically colonize only the lining of the natal gallery. In rare cases, these fungi cause serious damage in host trees, for example, R. quercus-mongolicae and R. quercivora on Quercus spp., and F. euwallaceae on diverse host species $[1,97,98]$. However, in these and other cases in which significant damage occurs, the fungal symbiont does not move systemically in host xylem and causes only localized damage; in these situations, tree mortality is associated with mass attack by the beetle vectors. Raffaelea lauricola is a unique symbiont, in that it systemically infects tree xylem and a single infection of susceptible trees can be fatal.

The population of $R$. lauricola in the United States is genetically uniform, apparently resulting from a single founding event (perhaps the importation of X. glabratus to Port Wentworth, Georgia). Little to no genetic variation was detected in isolates of the pathogen across the southeastern United States when Amplified Fragment Length Polymorphisms (AFLPs) and microsatellite markers were used [17]. With the same microsatellite markers and sequences of the large subunit of ribosomal (LSU) DNA, Wuest et al. [37] also concluded that the population of R. lauricola in the United States was quite uniform, in contrast to far greater diversity that they detected in the pathogen in Japan and Taiwan. When isolates from Asia were tested on avocado and swamp bay, they were as pathogenic as isolates 
from the United States [36,38]. Thus, although greater genetic diversity in R. lauricola has been found in Asia, differences in pathogenicity have not been apparent when isolates from the two regions have been compared.

The role of symbiont pathogenicity in the ecology of ambrosia beetles is not well understood [1,99]. Evident by comparison with other introductions is that the aggressiveness by which the laurel wilt pathogen systemically colonizes its North American tree hosts and causes lethal vascular wilt is an extreme scenario [1]. The range of fungal-specific damage observed among ambrosia symbionts in their native habitats varies from asymptomatic (nonpathogenic) to localized damage and host recovery (mildly virulent).

From the perspective of fungal pathogenicity, two hypotheses may help to understand the extreme aggressiveness of $R$. lauricola on North American Lauraceae. The first of these is that $R$. lauricola is an "accidental pathogen". Adaptations that enable $R$. lauricola to colonize natal galleries may, when encountered beyond the coevolved range of hosts, result in a massive host defense response that ultimately leads to xylem dysfunction and host death. The second hypothesis is that pathogenicity is a selective force in Asia that is kept in balance by coevolutionary processes; susceptible hosts, such as the naïve laurels in the southeastern United States, are eliminated, whereas those that tolerate infection persist and eventually replace their susceptible relatives.

Tests of these hypotheses are underway by comparing genomes of $R$. lauricola and its close relatives [100]. These analyses are aided by recently published phylogenies of Raffaelea [101,102], which have identified the closest, extant relatives of R. lauricola; notably, all other members of the phylogenetic clade in which $R$. lauricola resides (Raffaelea sensu stricto) are not plant pathogens. Of particular interest are genome-wide comparisons between $R$. lauricola and its close relative $R$. aguacate D. R. Simmons, Dreaden and Ploetz. Raffaelea aguacate has only been recovered from avocado [102], but it is neither systemic nor pathogenic on avocado or redbay [103]. Evidence for the accidental versus adapted pathogen hypotheses is being sought in comparative analyses between these two genomes and among genomes of related species. Virulence gene content, including those for putative effectors, elicitors and toxins, will be assessed, as will the expansion of these pathogenicity-associated gene families, and evidence for diversifying selection among candidate virulence factors.

Unraveling these fundamental questions may provide significant insight and predictive value for what might be expected in the future. If all ambrosial symbionts have the potential to be plant pathogens, is it a matter of time before another beetle-fungus-tree combination facilitates the emergence of another laurel wilt-like pathogen ("symbiont roulette")? If, on the other hand, pathogenicity is a derived character, what are the attributes required for weakly pathogenic symbionts to be aggressive pathogens when introduced outside their native range?

\section{Hosts of Laurel Wilt}

The Lauraceae is a large family that includes over 50 genera and 2500 to 3000 species [104]. The family represents some of the earliest angiosperms and has a fossil record dating back to the Mid-Cretaceous [105]. It is well represented on both sides of the Pacific Basin, and the so-called "amphi-Pacific tropical disjunction" of the Persea and Cinnamomum groups in the family has been examined to understand the presence, and the origins and relatedness, of family members in the Eastern and Western Hemispheres [101,106,107].

Although there are notable exceptions, such as naturalized populations of camphortree in the southeastern USA and the globally cultivated crop, avocado [108,109], most species in the family have restricted distributions. In the American tropics, lauraceous taxa comprise significant portions of lowland forests and montane environments [110,111]. Considering their ecological importance, laurel wilt could have an even greater impact as it spreads to new areas in the Western Hemisphere.

Of economic concern is the potential impact of the disease in currently unaffected avocado-production areas [28]. Avocado is a subtropical/tropical tree, and a significant fruit crop. In 2014, 5 million metric tonnes (MMT) of fruit were harvested worldwide, and Mexico was the 
leading producer (1.5 MMT) and exporter (in 2013, 0.6 MMT valued at ca. US\$1.1 billion) [112]. Depending on the cultivars that are grown, which vary considerably in cold tolerance, the crop is grown commercially from United States Department of Agriculture Hardiness Zones 10 to 11, with moderate urban production of some cultivars occurring into Zone 9. Florida's avocado industry is the state's second-largest fruit industry after citrus, and $85 \%$ of the producers have orchards of less than 13 hectares. In the United States, more than 6600 growers on mostly small farms (less than 45 hectares) produce avocado; annual production worth more $\$ 1.6$ billion is at risk [112].

Laurel wilt has affected avocado in Florida for at least a decade, but so far only ca. $3 \%$ of the avocado trees in commercial production have been killed [113]. However, the short time laurel wilt has been in South Florida (where most commercial production occurs), the great susceptibility of avocado to this disease, and experience with other lethal, invasive diseases [11,114] suggests that laurel wilt will, in the future, cause increasing damage on avocado in Florida. Laurel wilt imperils avocado production in other states (e.g., California and Hawaii), USA protectorates (Puerto Rico) and neighboring countries such as Mexico [28].

Persea americana is divided into Mexican (M), Guatemalan (G) and West Indian (WI) (also known as Lowland or Antillean) botanical races, respectively vars. drymifolia (Schltdl. and Cham.) S.F. Blake, guatemalensis (L. O.Williams) Scora, and americana Mill. [115]. Hybridization occurs freely among the races and is associated with a range of responses to calcareous soil, salinity, high and low temperatures, and other stresses $[109,116]$. Different responses to laurel wilt have also been noted among the races and racial combinations of the species; in general, greater susceptibility occurs in WI cultivars $[117,118]$.

Although the most serious outbreaks of laurel wilt have occurred on lauraceous natives from the southeastern United States, a few natives from the region, gulf licaria and lancewood, display moderate tolerance after artificial inoculation $[32,119]$. They develop vascular symptoms, but do not die, which is similar to the response of camphortree [33]. Notably, rare tolerance to laurel wilt has been selected in redbay, and there is hope that these selections could be used to re-establish this tree in the southeastern coastal plain $[36,120]$.

More data are needed on the susceptibility of American and non-American species in the family, and how susceptible and resistant hosts respond to infection by $R$. lauricola. To date, we have only rudimentary understandings of these processes [33,121-123]. Although natural selection against susceptibility has probably occurred in camphortree and other Asian Lauraceae [1,33], host attributes that are associated with laurel wilt tolerance have been studied only recently [121].

\section{Host Responses to Infection by Raffaelea lauricola}

Vascular wilt diseases typically exhibit wilting, sapwood discoloration (Figure 1D) and vascular dysfunction associated with physical and histological changes in the host [124]. The production of gels [125] and tyloses [126] in the xylem are two of the most common attributes of affected woody plants [127-131].

Tyloses are formed in xylem lumena in response to pathogen infection, embolism, aging, and injury [131]. They are outgrowths from adjacent parenchyma cells, and even though they can prevent desiccation, damage, and infection of adjacent cells [131], they also reduce hydraulic conductivity (water conductance) [132]. Gels induced by pathogens generally arise from host perforation plates, end walls, and pit membranes of the primary wall and middle lamella $[131,133,134]$. Breakdown of these cellular components by the pathogen results in the accumulation of gels [135].

Symptoms of laurel wilt on avocado, redbay, and swampbay include rapid wilting of foliage and vascular discoloration (Figures 1D,E and 2). Xylem blockage associated with tylose and gel formation appears to be at least partially responsible for the wilting symptoms [122,123]. Xylem function (the ability to conduct water) in avocado is impaired as soon as 3 days after inoculation, before the development of external or internal symptoms of the disease are apparent [123] (Figure 3). Tree mortality is associated with vascular functionalities of less than $10 \%$. 
Artificial inoculations with as few as 100 conidia of $R$. lauricola can kill avocado and swamp bay [136]. After laurel wilt-susceptible (avocado and swamp bay) and tolerant (camphortree) hosts were inoculated with a green fluorescent protein (GFP)-labelled strain of $R$. lauricola, Campbell et al. [120] reported that the pathogen was scarcely visible in microscopic cross sections, even in dead or dying plants. Although they observed that a maximum of $0.9 \%$ of the xylem lumena of avocado were colonized by the GFP-labelled strain 30 days after inoculation (dai) (Figure 4), about $40 \%$ of the lumena of avocado were occluded by tyloses 21 dai in another study [123] (Figure 5). Mobility of the pathogen or its metabolites in the xylem seems to be related to susceptibility.

Symptom development has been associated with reduced water transport in other, similar tree diseases. Wych elm affected by Dutch elm disease (caused by Ophiostoma novo-ulmi Brasier) [137], bitternut hickory affected by hickory decline (Ceratocystis smalleyi J. A. Johnson and T. C. Harr. [138], Quercus spp. affected by Japanese oak wilt (R. quercivora) [139], and Notholithocarpus (formerly Lithocarpus) densiflorus (Hook. and Arn.) Manos, Cannon and S.H.Oh affected by sudden oak death (Phytophthora ramorum Werres et al.) [140] all exhibited reduced xylem function which was, in turn, correlated with symptom development. For example, Park et al. [138] detected an inverse relationship between xylem sap flow and sapwood infection by C. smalleyi. They proposed that tylose formation induced by infection was responsible for reduced water transport in affected trees; C. smalleyi caused multiple cankers and reduced xylem function, resulting in crown wilt and decline of bitternut hickory.

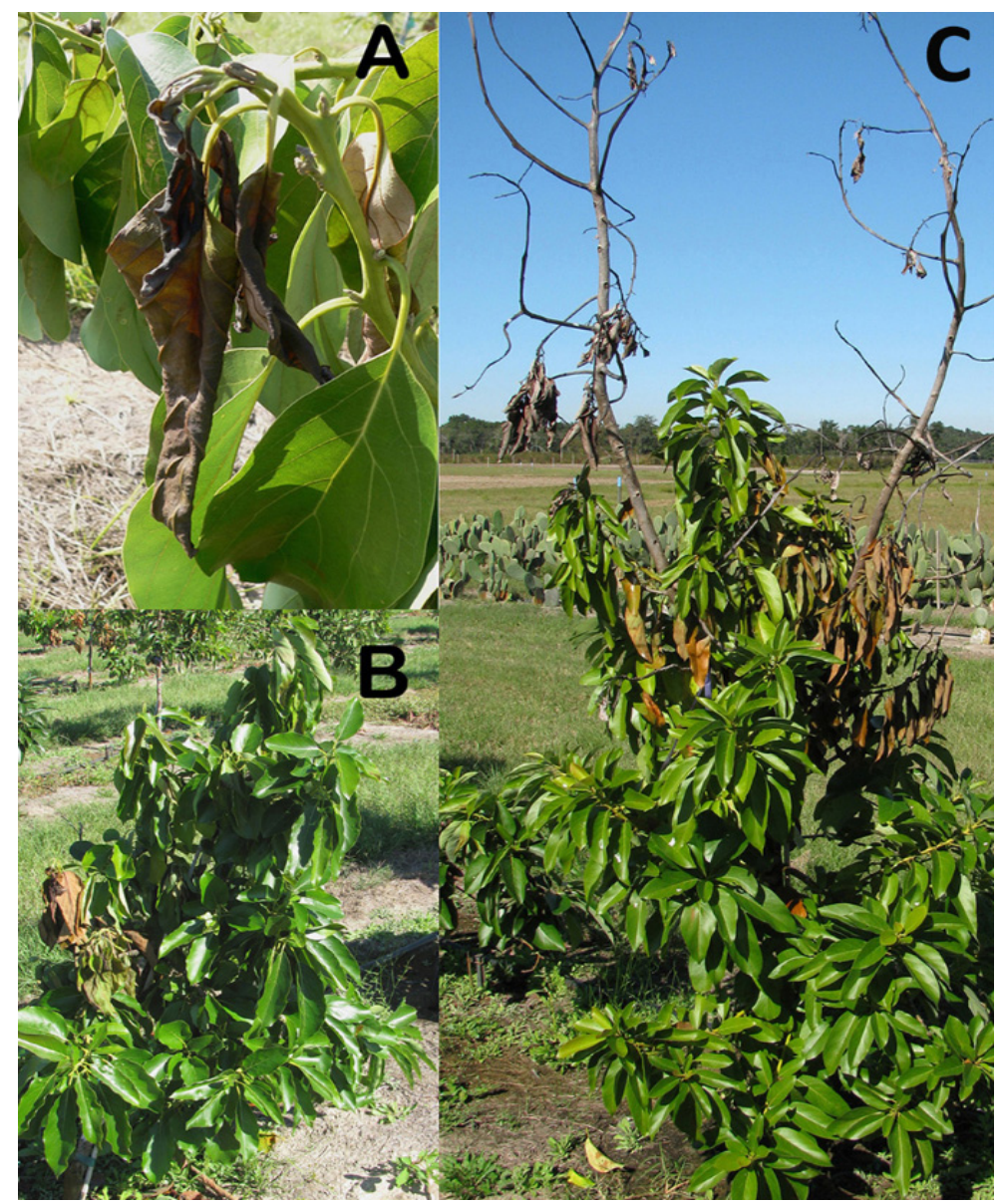

Figure 2. Foliar symptoms of laurel wilt on avocado include (A) wilting and an oily grey discoloration that rapidly progresses to necrosis; (B) initial symptom development in only a portion of a tree's canopy, involving a limited number of vascular traces; and $(\mathbf{C})$ involvement of greater portions of the canopy followed by defoliation within a month or two of symptom onset (far more rapidly than occurs in redbay and other native Persea spp.) (photos: R. Ploetz). 

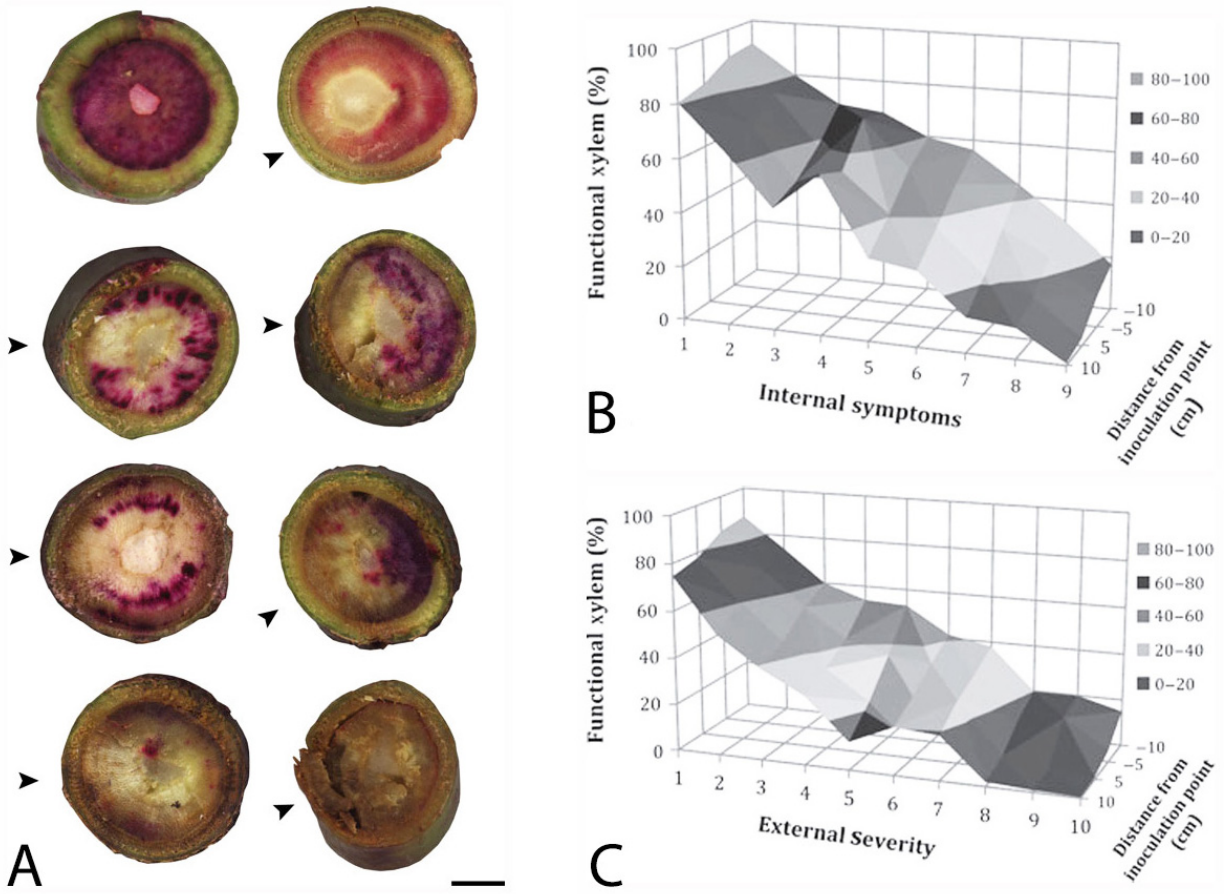

Figure 3. "Simmonds" avocado trees were inoculated with Raffaelea lauricola and xylem function was assessed with an acid fuchsin stain [122]. In (A), burgundy to pink staining in stem sections indicates functional xylem, which was quantified in scanned, digital images. From left to right and top to bottom, xylem in cross sections are: $98 \%$ functional (water control, internal symptoms (is) $=1 ; 86 \%$ (3 days after inoculation (dai) ), is = $1 ; 76 \%$ (7 dai, is = 2$) ; 71 \%(14$ dai, is $=3) ; 32 \%(21 \mathrm{dai}$, is $=5) ; 30 \%$ (21 dai, is $=6$; $5 \%$ (42 dai, is $=9$; and $1 \%$ (42 dai, is $=9)$. Arrows $\left(^{(}\right)$indicate the position on a stem that was inoculated, and the scale bar $=0.5 \mathrm{~cm}$. In the response surfaces, $\%$ of functional xylem is graphed on the y-axes against the distance from the inoculation point on the $\mathrm{z}$-axes and (B) internal and (C) external symptom development on the $x$-axes, which was rated on a 1-10 scale, where $1=$ healthy, no symptoms, and $10=$ dead, totally symptomatic.

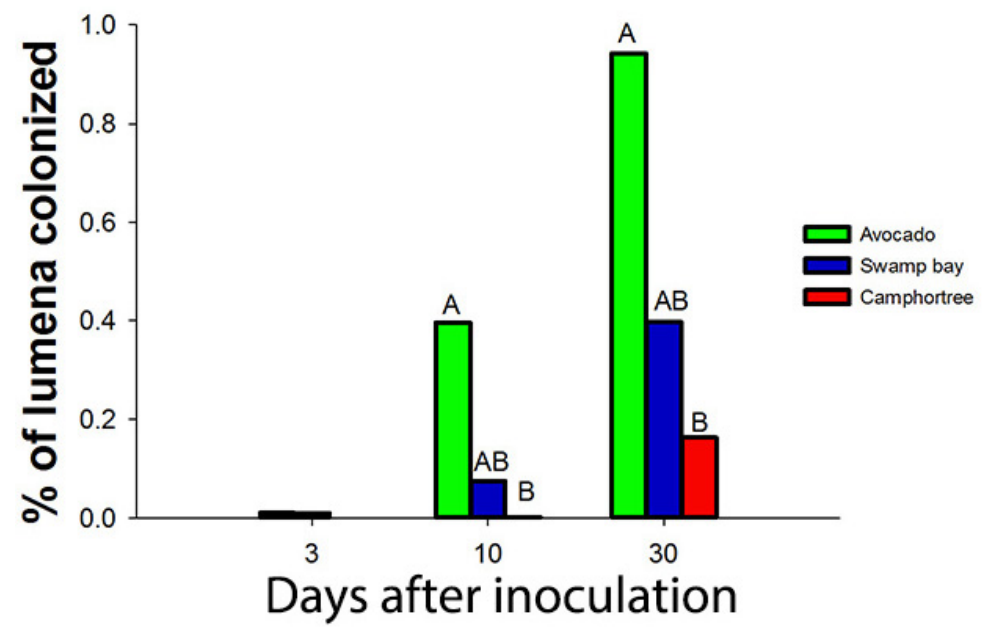

Figure 4. Campbell et al. [121] observed that less than $1 \%$ of the lumena of avocado, swamp bay and camphortree were colonized with a GFP-labelled strain of Raffaelea lauricola, even 30 days after inoculation (dai) (when most plants of avocado and swamp bay had died from laurel wilt). 


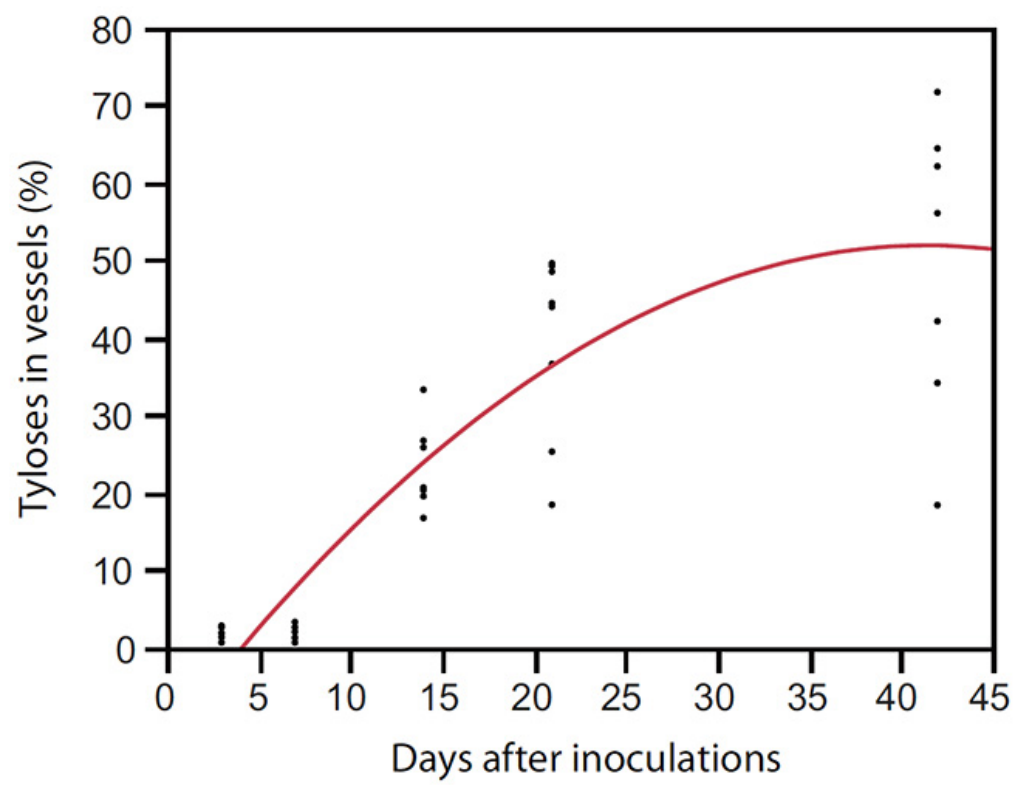

Figure 5. "Simmonds" avocado was artificially inoculated with Raffaelea lauricola and xylem lumena were examined in stem cross sections for tylose formation 7,14 and 42 days after inoculation $\left(R^{2}=0.78\right.$, $\left.y=-0.69+1.79 x-0.04(x-17.4)^{2}, p<0.0001\right)[123]$.

Ploetz et al. [118] hypothesized that an avocado scion's susceptibility to laurel wilt is related to its ability to conduct water. They observed that pre-inoculation sap flow rates were greater $(p=0.05)$ in a susceptible cultivar, "Russell" WI, compared to the less susceptible cultivars "Brogdon" M $\times \mathrm{G} \times \mathrm{WI}$ and "Marcus Pumpkin" G; however, sap flow plummeted in "Russell" soon after inoculation. Recently, Campbell et al. [121] reported that cross sections of xylem lumena of "Simmonds", another WI avocado cultivar, were nearly 2.5 times larger $\left(3063 \mu \mathrm{m}^{2} \pm 226\right)$ than those of camphortree $\left(1250 \mu \mathrm{m}^{2} \pm 221\right)$. Although they indicated that wood chemistry might impede the development of $R$. lauricola in camphortree (it contains antifungal compounds [141]), they also observed that smaller lumena in camphortree could hinder the movement of $R$. lauricola compared to host trees with larger lumena.

In long-term studies to develop elms that resist Dutch elm disease, vessel size and sap flow were reported to be key factors associated with the susceptibility of Ulmus minor Mill. and Ulmus hybrids [142-144]. Susceptible trees had significantly wider and longer vessels than those that resisted the disease [144]. Solla and Gil [142] hypothesized that vessel diameters and sap flow affected the dispersal of O. novo-ulmi in the elm host, and Venturas et al. [144] suggested that xylem structure restricted the pathogen's spread in resistant elms.

Additional work is needed to understand the relationship between susceptibility to laurel wilt and sap flow and other xylem-associated attributes, as it may facilitate the identification of laurel wilt-tolerant genotypes of host trees. Whether sap flow rates and xylem attributes are general predictors of laurel wilt susceptibility and tolerance in avocado are examined in ongoing work.

\section{Ecology and Epidemiology}

To date, native Persea spp. (redbay, swamp bay and silk bay, which some refer to collectively as redbay) have been most severely impacted by laurel wilt. Within a few years of affecting a stand, most mature trees of these species succumb to this disease $[13,21,22,145,146]$. Symptoms of laurel wilt develop soon after host trees are infected by R. lauricola (usually within 2 to 3 weeks of artificial inoculation) [117]. As the disease develops, host trees increase the production of volatiles that attract $X$. glabratus [92], which then promotes mass attack, colonization and brood development by X. glabratus.

The explosive nature of the laurel wilt epidemic is due to the great susceptibility of the native Persea spp. [26], their attractiveness to X. glabratus [66,78], the rapid increase in X. glabratus numbers 
in affected stands of these trees [58], and the substantial amounts of inoculum that most females of X. glabratus carry [70]. Furthermore, tree-to-tree spread via interconnected root systems, which has been suspected in avocado [28] and sassafras [147], and demonstrated in pondberry [148], enables movement of the pathogen without vector assistance. It is hard to imagine a more efficient means for killing trees than this disease.

Raffaelea lauricola typically infects avocado only via ambrosia beetle vectors and interconnecting root grafts (see below), although other avenues of infection have been studied experimentally. Mechanical transmission of the pathogen was possible with artificially infested handsaws on potted plants, but the pathogen did not survive on circular saws that are used to prune avocado trees in commercial groves, presumably due to the high heat that was generated on these blades during use [149]. Seed and scion transmission of $R$. lauricola have also been discounted. After potted, fruit-bearing trees were artificially inoculated with $R$. lauricola plants were systemically colonized by the fungus, but in no instance did infection progress further than the hilum of fruit (87 fruit and their associated pedicles) [150]. Furthermore, when scions from artificially infected trees were used as grafting material, they did not establish on recipient rootstocks [151].

Most commercial avocado production in the eastern United States is located in Miami-Dade County in southern Florida; it is bordered on the north and east by metropolitan Miami and on the west and south by Everglades National Park (ENP) [152,153]. The proximity of a densely populated urban area and a protected natural area creates significant challenges for managing this disease.

Residential avocado trees are common in Miami. In other pathosystems, residential trees can act as reservoirs for pathogens from which neighboring agricultural areas are colonized. For example, residential trees played a significant role in epidemics of citrus canker in Florida and plum pox in Canada [154,155]. Residential trees are also associated with the regional spread of pathogens via the nursery trade, as infected asymptomatic plants can be sold and distributed through this network [156,157]. In this case, the short latent period of laurel wilt on susceptible hosts may be advantageous, as asymptomatic infection of these species would probably play a negligible role in spreading the disease. In contrast, tolerant species, such as camphortree, could serve as symptomless reservoirs of $R$. lauricola and X. glabratus in the landscape as well as a means by which the disease could spread; greater understanding of their potential role in the regional dissemination of this disease is needed.

Natural areas that border avocado production areas in southern Florida may present risks similar to those of residential avocado trees. Prior to the laurel wilt epidemic, swamp bay occurred throughout the ENP. Swamp bay is highly susceptible to laurel wilt [26] and is attractive to, and supports significant egg production of, X. glabratus [158]. An aerial survey of the Everglades in 2011 and 2013 detected rapid spread of laurel wilt on this host tree [25]. Since source-to-sink dynamics from unmanaged areas to agricultural areas have played an important role in other diseases with insect vectors [159], there was concern that swamp bay trees might act as disease and vector refugia in the ENP. However, recent spatial analyses suggested that laurel wilt outbreaks in the avocado production area are concentrated there, and that there is little connectivity between laurel wilt in the avocado and natural areas [160].

Once laurel wilt has established in an avocado orchard, it apparently moves among trees through root grafts [28]. Root grafting (i.e., the establishment of functional unions between the roots of different plants), is a common phenomenon in trees [161,162], and it plays a significant role in the movement of similar plant pathogens, such as those that cause oak wilt (Ceratocystis fagacearum (Bretz) Hunt) and Dutch elm disease (Ophiostoma spp.) [163-165]. In avocado orchards, high densities of trees are planted in rows in which root grafting occurs among adjacent trees. Previously, the root-graft movement of herbicides and another avocado pathogen, Avocado sunblotch viroid (ASBVd), were recognized [117,166-168]. Subsequent evidence that root-graft transmission of R. lauricola occurs has included the natural infection of roots by the pathogen, rapid expansion of disease foci, and the fact that prompt fungicide treatment of trees adjacent to diseased trees impedes spread and expansion of foci $[28,117]$. 
Preventing root-graft spread in avocado orchards is difficult. Since trenching to sever root grafts stops the spread of oak wilt and Dutch elm disease, it would presumably be useful in laurel wilt-affected avocado orchards. However, trenching would damage irrigation systems that are typically in place in avocado orchards. Other techniques to limit root graft spread are being explored, such as establishing barriers to pathogen movement with fungicide or herbicide treatments $[28,169]$. Since root grafts tend to develop in older plants, maintaining younger orchards and smaller trees might also inhibit transmission among trees.

While root-graft transmission enables rapid movement of the pathogen among trees, transmission also occurs among and within orchards via ambrosia beetles. As discussed above, X. glabratus is most important in natural settings, as it predominates in both trapping and rearing assays with these host trees $[26,28,66]$, carries the greatest amounts of the pathogen [70], and was most consistently associated with transmission in no-choice assays [69]. However, the role that this species and its relatives play in the avocado system requires further study. The above spatial analyses [160] suggest that laurel wilt in swamp bay populations in the Everglades (on which X. glabratus would predominate) plays an insignificant role in the avocado epidemic. All of these data suggest that a complex of beetles, which may or may not include X. glabratus, are involved in laurel wilt dissemination in avocado. These beetles are understudied, and relatively little is known about their habits and roles in the environment. Understanding the ecological drivers of these insects is critical for future assessments of disease risk.

An early epidemiological model suggested that X. glabratus would not reach the southern tip of Florida until approximately 2015 [170]. However, X. glabratus was observed in Miami-Dade County in early 2010, and laurel wilt was reported in 2011 [153]. While this model accounted for host density and climatic features that benefit X. glabratus, it likely underestimated the effects of anthropogenic spread [170].

Although assigning an anthropogenic role to an outbreak of laurel wilt can be difficult, large geographic jumps in the disease's distribution and the close proximity of an outbreak to parks or other places where firewood is used, or where wood or wood products are handled, are attributes that suggest human agency. For example, Cameron et al. [171] reported outbreaks of laurel wilt in Georgia near a pulp mill and mulch plant. They also noted an apparent firewood-related outbreak near a campsite $120 \mathrm{~km}$ from the nearest outbreak. As this disease has spread, others have noted large jumps in its distribution. Riggins et al [172] reported a laurel wilt outbreak in Mississippi, over $500 \mathrm{~km}$ from the nearest known outbreak, and a recent finding in Texas was $300 \mathrm{~km}$ from the nearest known occurrence [16]. The above findings have been on redbay, but sassafras has also been impacted. Bates et al. [173] noted an outbreak on sassafras in Alabama, $160 \mathrm{~km}$ from the nearest outbreak, Fraedrich et al. [174] described an outbreak in Louisiana, $400 \mathrm{~km}$ from the nearest outbreak, and Olatinwo et al. [175] described a subsequent finding in Arkansas, $134 \mathrm{~km}$ north of the Louisiana outbreak. These range expansions suggest that anthropogenic spread is an important factor in the epidemiology of this disease. In addition, the increased prevalence of laurel wilt on sassafras, a common species that extends into Canada and which supports propagation of X. glabratus, indicates that the disease has the potential to continue its northward movement.

Effective landscape modeling of laurel wilt will need to account for biological (e.g., host range, host density and vector competency) and social factors (e.g., proximity to campgrounds and areas in which wood or wood products are handled). Integrating these factors is critical for understanding long-term disease prevention and control. Shearman et al. [176] used forest inventory and analysis data to estimate risk factors for redbay. They determined that the presence of laurel wilt in a county increased the odds that a given tree would be killed by approximately $154 \%$, for every year after the initial outbreak, and that mortality rates increased by $5 \%$ for increases of $1 \mathrm{~cm}$ diameter breast height $(\mathrm{DBH})$ in a tree's trunk diameter.

Epidemic network analysis is becoming a common part of the epidemiological toolbox $[177,178]$. Harwood et al. [179] used network analysis to evaluate likely outcomes for epidemics caused by 
P. ramorum and P. kernoviae in the United Kingdom, as influenced by inspection strategies. These pathogens can spread through natural systems, as well as the nursery trade. They concluded that if the rates at which these pathogens were introduced increased, inspection activities could not keep up with the influx. Network analysis has also been used to identify key sampling locations for tracking epidemic progress $[180,181]$. For laurel wilt, spread via infested wood is a key vulnerability for long-distance movement, but this activity is difficult to monitor. To the extent that epidemic network structures can be characterized for a disease such as laurel wilt, strategies may be implemented to make inspection more efficient.

Impact Network Analysis [182] is a multilayer network analysis that uses agent-based modeling [183] to evaluate the likely system-level effects of regional management implementation. Multilayer networks integrate linked processes, such as networks of the spread of information about disease and linked networks for the spread of the disease and/or its vectors [180,184-186]. Multilayer networks can provide analyses about how networks interact to produce system level outcomes.

In Impact Network Analysis, three components are emphasized [182]. The first is a management concept or tool, such as a recommended cultural practice, a resistant variety, or effective pesticide, which is associated with a level of efficacy, a level of confidence in the estimated efficacy, and the cost of implementation. The second component is the network of communication and influence among managers who decide whether to implement the management tool [187], as well as the management landscape (e.g., natural or agro-ecosystem) in which management is or is not applied. The third component incorporates information on the epidemic network. Notably, establishment of a given disease in a new location may be strongly influenced by the management landscape. Impact Network Analysis is a platform for evaluating how a proposed management type or portfolio of management types is likely to influence regional epidemics, including the effects of manager decision-making [182].

An Impact Network Analysis is being developed for the laurel wilt epidemic in Florida and beyond. When the first component of the analysis is considered, the tools that are available for management are somewhat disheartening (see below). Currently, in natural systems that are populated by highly susceptible host species, there are no viable measures. Furthermore, although there are effective tools for avocado production, they are not consistently adopted by producers. The second component of the analysis, the network of communication and influence among managers, presents additional challenges. For example, some avocado managers may not be convinced of the importance of management, or may be motivated to manage only minimally until land is diverted for other purposes. The third component, the epidemic network, indicates that unmanaged outbreaks of laurel wilt are important risk factors in the avocado system. Growers who do not effectively manage laurel wilt may increase the difficulty with which the disease is managed by other avocado producers. Additionally, the impact of residential avocado production is a poorly understood, but potentially important facet of the epidemic network.

Serious challenges exist for managing laurel wilt in most situations. However, if laurel wilt epidemics in natural systems are shown to exert little or no influence on the avocado system, regional avocado management strategies could be simplified. Understanding the regional system will be a first step toward scaling up [188] risk assessment and management strategies in Cuba, Mexico and neighboring avocado-production areas.

Early detection of laurel wilt (ideally $R$. lauricola-infected trees before they develop symptoms) is critical to the containment of laurel wilt and the success of disease management efforts in avocado orchards. Since symptoms of laurel wilt can be confused with those associated with other biotic and abiotic factors, the presence of $R$. lauricola should be confirmed when a laurel wilt diagnosis is in doubt $[26,28]$. Currently, a taxon-specific method can be used to identify the pathogen and distinguish it from its closest relative, $R$. aguacate [102,189].

Visible-near infrared spectroscopy has been tested for the nondestructive detection of laurel wilt on avocado [190]. Classification studies were conducted with visible near infrared spectra of asymptomatic and symptomatic leaves from plants artificially infected with $R$. lauricola, as well 
as leaves from noninfected freeze-damaged and healthy plants. Scores from principal component analyses were used as input features in four classifiers: linear discriminant analysis, quadratic discriminant analysis, Naïve-Bayes classifier, and bagged decision trees. All of the classifiers were able to discriminate leaves from plants with laurel wilt from freeze-damaged leaves. False negatives resulted mainly from asymptomatic leaves from infected plants being classified as healthy.

In subsequent work, spectral data were used to distinguish healthy, laurel wilt-affected, and Phytophthora root rot-affected avocado trees [191]. With a modified camera, spectral images were taken during helicopter surveys of commercial avocado orchards [192]. RmodGB digital data were used to calculate vegetation indices (VIs), band ratios, and VI combinations for healthy and laurel wilt-affected trees. Significant differences were observed in all VIs calculated among laurel wilt affected and healthy trees, although the best results were achieved with Excess Red, (Red-Green) and Combination 1 . These results were used to modify a MCA-6 Tetracam camera with different spectral filters (580-10 nm, 650-10 nm, 740-10 nm, 750-10 nm, 760-10 nm and 850-40 nm), which was then used to take multispectral images of avocado trees at early, intermediate and late stages of laurel wilt development at three altitudes (180, 250 and $300 \mathrm{~m})$ [191]. Inexpensive devices that use this technology need to be developed.

Canine detection was recently promoted for detecting avocado trees infected with R. lauricola, prior to the development of laurel wilt symptoms [193]. Although there has been some success in detecting other diseases under controlled settings [194], data for canine detection of laurel wilt has only been presented in seminars (no peer reviewed publications are available). Recently, canine detection was reported in avocado trees that displayed no obvious symptoms of laurel wilt [195]. Although R. lauricola was not isolated from $42 \%$ of the "detected" trees, in another avocado orchard, laurel wilt subsequently developed in most of the detected trees. Thus, trees from which the pathogen had not been isolated were, presumably, infected with $R$. lauricola when detected by dogs.

The reliability of canine detection requires additional evaluations. For example, the ability of dogs to distinguish infection in root-grafted trees, detect the pathogen prior to symptom development (see [196]), and distinguish R. lauricola from its close relatives, many of which are prevalent in ambrosia beetles that infest avocado [102,197], should be determined. Nonetheless, the available evidence suggests that canine detection could be a useful tool for managing laurel wilt in avocado orchards.

As alluded to above, the spread of laurel wilt is affected by poorly understood social factors. For example, even though early detection could help stem its spread the avocado system, producers might not adopt the available techniques (the second component in the above Impact Network Analysis). Furthermore, early detection would only be effective if detected trees were then promptly removed (sanitation) or treated with fungicide. Agricultural producers respond to uncertainty in different ways, and only a subset of all producers will adopt a given technology, no matter how effective it might be. Better understandings are needed for the impacts of different social, economic, and cognitive factors on the decision making process [183,198].

Laurel wilt management in commercial avocado orchards is possible, but difficult [199]. Effective fungicide treatments have been described, but they are expensive and their use may not be sustainable. Annual retreatment is indicated for even the best fungicide treatments. It becomes increasingly difficult to retreat trees as they heal from previous applications (wound tissue impedes fungicide uptake in previously treated sites). Subsequent applications are forced to move above the root collar, which is the most effective application site. Early detection and the rapid removal and destruction of affected trees is a more effective measure for managing this disease, but its adoption varies widely among producers. Retaining infected trees in an orchard is a dangerous, but common practice, as many producers are averse to removing trees that might produce fruit. Once focal development of the disease (root-graft movement of the pathogen) begins, laurel wilt becomes incredibly difficult to manage. In general, avocado producers who have been forced out of production by laurel wilt have practiced tardy and insufficient management. 
In natural environments that are impacted by laurel wilt, the above management strategies are not useful; in these situations, eradication of the disease is not possible, sanitation has been ineffective when it has been used, and fungicide treatment is far too expensive [26,200]. Nonetheless, laurel wilt-tolerant individuals of redbay have been identified [120]. Although it would be a long-term proposition, these selections might be useful for re-establishing devastated populations of this important species.

\section{Outlook}

Laurel wilt has changed the composition of forests throughout the southeastern United States [26]. It has eliminated redbay and swamp bay, two keystone species, from major portions of the region, and other important species, such as sassafras, will be increasingly impacted as the disease spreads. Other rare suscepts, such as pondberry, are threatened with extinction [24].

Time will tell when and whether new areas are affected by this destructive tree disease [28]. The ultimate impact of laurel wilt will be determined by which areas are invaded, the susceptibility of hosts that occur in these areas, the suite of vectors that are involved in new outbreaks and their effectiveness in transmitting $R$. lauricola. Clearly, ecosystems in the western United States and tropical America that are populated by suscepts are at risk [26,28].

Laurel wilt has begun to cause alarming losses in avocado production in Florida [28]. The state's primary commercial production area was first affected in 2012, and losses will continue to increase as the disease consolidates and spreads in the area. The economic impact of laurel wilt could increase dramatically when and if it spreads to California, Mexico and other major production areas.

Much remains to be learned about this enigmatic disease. Basic information is lacking on vector $x$ host $x$ pathogen interactions, vector identity and ecology in the avocado system and the disease's epidemiology in natural and agricultural environments. More data are needed on the disease's host range and the nature of resistance and susceptibility. Until better information is available in these and other areas, laurel wilt will remain a destructive disease for which we have few management options.

\section{Conclusions}

Laurel wilt is caused by the only known systemic and lethal ambrosia beetle symbiont, R. lauricola. To date, all suscepts are naïve trees in the Lauraceae plant family that do not have an evolutionary history with this pathogenic symbiont. In little more than a decade, laurel wilt spread throughout the southeastern coastal plant of the United States. Significant populations of native trees have been eliminated by the disease, and an important fruit crop, avocado, is affected in southern Florida and threatened in other production areas. Advances have been made in understanding the interactions of the pathogen with various host trees, as well as how the host responds to the disease. The disease's epidemiology is generally understood, but important gaps remain in what is known about the ambrosia beetle vector portion of the puzzle, especially in the avocado system. Although progress has been made in the management of laurel wilt, successful control in avocado production is still difficult, and in natural systems is all but impossible. An increasing impact of laurel wilt is predicted as it spreads within and beyond its present range.

Acknowledgments: This research was partially funded by USDA grants from the Florida Department of Agriculture and Consumer Services, FDACS Sponsor \#019730 and \#021757, the USDA-ARS National Plant Disease Recovery System, and NIFA grants 2009-51181-05915 and 2015-51181-24257.

Author Contributions: P.E.K. wrote the section on vector chemical ecology and host location, R.A.C. and K.G. wrote portions of the ecology and epidemiology section, J.A.R. wrote portions of the section on pathogen attributes, A.C. wrote portions of the section on host responses to infection, M.H. wrote portions of the sections on pathogen attributes and ecology and epidemiology, and T.D. wrote some of the section on pathogen attributes. R.C.P. contributed to the above sections, wrote all other portions of the manuscript, and conceived and edited its content.

Conflicts of Interest: The authors declare no conflict of interest. 


\section{References}

1. Ploetz, R.C.; Hulcr, J.; Wingfield, M.; de Beer, Z.W. Ambrosia and bark beetle-associated tree diseases: Black Swan events in tree pathology? Plant Dis. 2013, 95, 856-872. [CrossRef]

2. Pautasso, M.; Schlegel, M.; Holdelrieder, O. Forest health in a changing world. Microb. Ecol. 2015, 69, 826-842. [CrossRef] [PubMed]

3. Wingfield, M.J.; Brockerhoff, E.G.; Wingfield, B.D.; Slippers, B. Planted forest health: The need for a global strategy. Science 2015, 349, 832-836. [CrossRef] [PubMed]

4. Wingfield, M.J.; Garnas, J.R.; Hajek, A.; Hurley, B.P.; de Beer, Z.W.; Taerum, S.J. Novel and co-evolved associations between insects and microorganisms as drivers of forest pestilence. Biol. Invasions 2016, 18, 1045-1056. [CrossRef]

5. Anderson, P.K.; Cuningham, A.A.; Patel, N.G.; Morales, F.J.; Epstein, P.R.; Daszak, P. Emerging infectious diseases of plants: Pathogen pollution, climate change and agrotechnology drivers. Trends Ecol. Evol. 2004, 19, 535-544. [CrossRef] [PubMed]

6. Lu, M.; Wingfield, M.J.; Gillette, N.; Sun, J.-H. Do novel genotypes drive the success of an invasive bark beetle-fungus complex? Implications for potential reinvasion. Ecology 2011, 92, 2013-2019. [CrossRef] [PubMed]

7. Fisher, M.C.; Henk, D.A.; Briggs, C.J.; Brownstein, J.S.; Madoff, L.C.; McCraw, S.L.; Gurr, S.J. Emerging fungal threats to animal, plant and ecosystem health. Nature 2012, 484, 186-194. [CrossRef] [PubMed]

8. Trumbore, S.; Brando, P.; Hartmann, H. Forest health and global change. Science 2015, 349, $814-818$. [CrossRef] [PubMed]

9. Anagnostakis, S.L. Chestnut blight: The classical problem of an introduced pathogen. Mycologia 1987, 79, 22-37. [CrossRef]

10. Ploetz, R.C. Diseases of tropical perennial crops: Challenging problems in diverse environments. Plant Dis. 2007, 91, 644-663. [CrossRef]

11. Rackham, O. Ancient woodlands: Modern threats. New Phytol. 2008, 180, 571-586. [CrossRef] [PubMed]

12. Wingfield, M.J.; Hammerbacher, A.; Ganley, R.J.; Steenkamp, E.T.; Gordon, T.R.; Wingfield, B.D.; Coutinho, T.A. Pitch canker caused by Fusarium circinatum-A growing threat to pine plantations and forests worldwide. Australas. Plant Pathol. 2008, 37, 319-334. [CrossRef]

13. Fraedrich, S.W.; Harrington, T.C.; Rabaglia, R.J.; Ulyshen, M.D.; Mayfield, A.E., III; Hanula, J.L.; Eickwort, J.M.; Miller, D.R. A fungal symbiont of the redbay ambrosia beetle causes a lethal wilt in redbay and other Lauraceae in the southeastern USA. Plant Dis. 2008, 92, 215-224. [CrossRef]

14. Haack, R.A. Exotic bark- and wood-boring Coleoptera in the United States: Recent establishments and interceptions. Can. J. For. Res. 2006, 36, 269-288. [CrossRef]

15. Rabaglia, R.J.; Dole, S.A.; Cognato, A.I. Review of American Xyleborina (Coleoptera: Curculionidae: Scolytinae) Occurring North of Mexico, with an Illustrated Key. Ann. Entomol. Soc. Am. 2006, 99, 1034-1056. [CrossRef]

16. Barton, C.; Bates, C.; Cutrer, B.; Eickwort, J.; Harrington, S.; Jenkins, D.; Stones, D.M.; Reid, L.; Riggins, J.J.; Trickel, R. Distribution of Counties with Laurel wilt Disease by Year of Initial Detection. Available online: http:/ /www.fs.usda.gov /Internet/FSE_DOCUMENTS/fseprd513913.pdf (accessed on 16 Feb 2017).

17. Hughes, M.A.; Riggins, J.J.; Koch, F.H.; Cognato, A.I.; Anderson, C.; Formby, J.P.; Dreaden, T.J.; Ploetz, R.C.; Smith, J.A. No rest for the laurels: Symbioclone invader causes unprecedented damage to southern USA forests. Biol. Invasions 2017, in press.

18. Goldberg, N.; Heine, J. A comparison of arborescent vegetation pre- (1983) and post- (2008) outbreak of the invasive species the Asian ambrosia beetle Xyleborus glabratus in a Florida maritime hammock. Plant Ecol. Divers. 2009, 2, 77-83. [CrossRef]

19. Gramling, J.M. Potential effects of laurel wilt on the flora of North America. Southeast Nat. 2010, 9, 827-836. [CrossRef]

20. Shields, J.; Jose, S.; Freeman, J.; Bunyan, M.; Celis, G.; Hagan, D.; Morgan, M.; Pieterson, E.C.; Zak, J. Short-term impacts of laurel wilt on redbay (Persea borbonia L. Spreng.) in a mixed evergreen-deciduous forest in northern Florida. J. For. 2011, 109, 82-88. 
21. Evans, J.P.; Scheffers, B.R.; Hess, M. Effect of laurel wilt invasion on redbay populations in a maritime forest community. Biol. Invasions 2013, 16, 1581-1588. [CrossRef]

22. Spiegel, K.S.; Leege, L.M. Impacts of laurel wilt disease on redbay (Persea borbonia (L.) Spreng.) population structure and forest communities in the coastal plain of Georgia, USA. Biol. Invasions 2013, 15, 2467-2487. [CrossRef]

23. Chupp, A.D.; Battaglia, L.L. Potential for host shifting in Papilio palamedes following invasion of laurel wilt disease. Biol. Invasions 2014, 16, 2639-2651. [CrossRef]

24. Fraedrich, S.W.; Harrington, T.C.; Bates, C.; Johnson, J.; Reid, L.; Leininger, T.; Hawkins, T. Susceptibility to laurel wilt and disease incidence in two rare plant species, pondberry and pondspice. Plant. Dis. 2011, 95, 1056-1062. [CrossRef]

25. Rodgers, L.; Derksen, A.; Pernas, T. Expansion and impact of laurel wilt in the Florida Everglades. Fla. Entomol. 2014, 97, 1247-1250. [CrossRef]

26. Hughes, M.A.; Smith, J.A.; Ploetz, R.C.; Kendra, P.E.; Mayfield, A.E., III; Hanula, J.L.; Hulcr, J.; Stelinski, L.L.; Cameron, S.; Riggins, J.J.; et al. Recovery plan for laurel wilt on redbay and other forest species caused by Raffaelea lauricola and disseminated by Xyleborus glabratus. Plant Health Progr. 2015, 16, 173-210.

27. Mosquera, M.; Evans, E.A.; Ploetz, R. Assessing the profitability of avocado production in south Florida in the presence of laurel wilt. Theor. Econ. Lett. 2015, 5, 343-356. [CrossRef]

28. Ploetz, R.C.; Hughes, M.A.; Kendra, P.E.; Fraedrich, S.W.; Carrillo, D.; Stelinski, L.L.; Hulcr, J.; Mayfield, A.E., III; Dreaden, T.L.; Crane, J.H.; et al. Recovery Plan for Laurel Wilt of Avocado, caused by Raffaelea lauricola. Plant Health Progr. 2017, 18, in press.

29. Hughes, M.A.; Shin, K.; Eickwort, J.; Smith, J.A. First report of laurel wilt disease caused by Raffaelea lauricola on silk bay in Florida. Plant Dis. 2012, 96, 910. [CrossRef]

30. Hughes, M.A.; Brar, G.; Ploetz, R.C.; Smith, J.A. Field and growth chamber inoculations demonstrate Persea indica as a newly recognized host for the laurel wilt pathogen, Raffaelea laurciola. Plant Health Progr. 2013. [CrossRef]

31. Hughes, M.A.; Black, A.; Smith, J.A. First report of laurel wilt, caused by Raffaelea lauricola, on bay laurel (Laurus nobilis) in the United States. Plant Dis. 2014, 98, 1159. [CrossRef]

32. Ploetz, R.C.; Konkol, J. First report of gulf licaria, Licaria trianda, as a suscept of laurel wilt. Plant Dis. 2013, 97, 1248. [CrossRef]

33. Fraedrich, S.W.; Harrington, T.C.; Best, G.S. Xyleborus glabratus attacks and systemic colonization by Raffaelea lauricola associated with dieback of Cinnamomum camphora in the southeastern United States. For. Pathol. 2015, 45, 60-70.

34. Hulcr, J.; Lou, Q.-Z. The redbay ambrosia beetle (Coleoptera: Curculionidae) prefers Lauraceae in its native range: Records from the Chinese national insect collection. Fla. Entomol. 2013, 96, 1595-1596. [CrossRef]

35. Harrington, T.C.; Yun, H.Y.; Lu, S.S.; Goto, H.; Aghayeva, D.N.; Fraedrich, S.W. Isolations from the redbay ambrosia beetle, Xyleborus glabratus, confirm that the laurel wilt pathogen, Raffaelea lauricola, originated in Asia. Mycologia 2011, 103, 1028-1036. [CrossRef] [PubMed]

36. Hughes, M.A. The Evaluation of Natural Resistance to Laurel wilt Disease in Redbay (Persea borbonia). Ph.D. Thesis, University of Florida, Gainesville FL, USA, 2013.

37. Wuest, C.E.; Harrington, T.C.; Fraedrich, S.W.; Yun, H.-Y.; Lu, S.-S. Genetic variation in native populations of the laurel wilt pathogen, Raffaelea lauricola, in Taiwan and Japan and the introduced population in the USA. Plant Dis. 2017, 101, in press.

38. Ploetz, R.C.; Thant, Y.Y.; Hughes, M.A.; Dreaden, T.J.; Konkol, J.L.; Kyaw, A.T.; Smith, J.A.; Harmon, C.L. Laurel wilt, caused by Raffaelea lauricola, is detected for the first time outside the southeastern USA. Plant Dis. 2016, 100, 2166. [CrossRef]

39. Erlich, P.R.; Raven, P.H. Butterflies and plants: A study in coevolution. Evolution 1964, 18, 586-608. [CrossRef]

40. Darwin, C.R. On the Origin of Species by Means of Natural Selection, or the Preservation of Favoured Races in the Struggle for Life; John Murray: London, UK, 1859.

41. Flor, H.H. Host-parasite interaction in flax rust-Its genetics and other implications. Phytopathology 1955, 45, 680-685.

42. Crute, I.R. The elucidation and exploitation of gene-for-gene recognition. Plant Pathol. 1998, 47, $107-113$. [CrossRef] 
43. Bergelson, J.; Dwyer, G.; Emerson, J.J. Models and data on plant-enemy coevolution. Annu. Rev. Genet. 2001, 35, 469-499. [CrossRef] [PubMed]

44. Kareiva, P. Coevolutionary arms races: Is victory possible? Proc. Natl. Acad. Sci. USA 1999, 96, 8-10. [CrossRef] [PubMed]

45. Burdon, J.J.; Thrall, P.H. Spatial and temporal patterns in coevolving plant and pathogen associations. Am. Nat. 1999, 153, S15-S33. [CrossRef]

46. Thompson, J.N. Specific hypotheses on the geographic mosaic of coevolution. Am. Nat. 1999, 153, S1-S14. [CrossRef]

47. Burdon, J.J.; Thrall, P.H.; Ericson, L. The current and future dynamics of disease in plant communities. Annu. Rev. Phytopathol. 2006, 44, 19-39. [CrossRef] [PubMed]

48. Haldane, J.B.S. Disease and evolution. La Ric. Sci. (Suppl.) 1949, 19, 68-76.

49. Harlan, J.R. Diseases as a factor in plant evolution. Annu. Rev. Phytopathol. 1976, 14, 31-51. [CrossRef]

50. Clay, K.; Kover, P.X. The red queen hypothesis and plant/pathogen interactions. Annu. Rev. Phytopathol. 1996, 34, 29-50. [CrossRef] [PubMed]

51. Schardl, C.L.; Leuchtmann, A.; Chung, K.-R. Coevolution by common descent of fungal symbionts (Epichloë spp.) and grass hosts. Mol. Biol. Evol. 1997, 14, 133-143. [CrossRef]

52. Holst-Jensen, A.; Kohn, L.M.; Jakobsen, K.S.; Schumacher, T. Molecular phylogeny and evolution of Monilinia (Sclerotiniaceae) based on coding and noncoding rDNA sequences. Amer. J. Bot. 1997, 84, 686-701. [CrossRef]

53. Evans, H.C. Invasive neotropical pathogens of tree crops. In Tropical Mycology: Volume 2, Micromycetes; CABI Publishing: Wallingford, UK, 2002; pp. 83-112.

54. O’Donnell, K.; Sink, S.; Libeskind-Hadas, R.; Ploetz, R.C.; Konkol, J.L.; Ploetz, J.N.; Carrillo, D.; Campbell, A.; Duncan, R.E.; Kasson, M.T.; et al. Cophylogenetic analysis of the Fusarium-Euwallacea (Coleoptera: Scolytinae) mutualism suggests their discordant phylogenies are due to repeated host shifts. Fungal Genet. Biol. 2015, 82, 277-290. [CrossRef] [PubMed]

55. Kirkendall, L.R. Ecology and evolution of biased sex ratios in bark and ambrosia beetles. In Evolution and Diversity of Sex Ratio: Insects and Mites; Wrensch, D.L., Ebbert, M.A., Eds.; Chapman and Hall: New York, NY, USA, 1993; pp. 235-345.

56. Jordal, B.H.; Normark, B.B.; Farrell, B.D. Evolutionary radiation of a haplodiploid beetle lineage (Curculionidae, Scolytinae). Biol. J. Linn. Soc. 2000, 71, 483-499. [CrossRef]

57. Jordal, B.H.; Cognato, A.I. Molecular phylogeny of bark and ambrosia beetles reveals multiple origins of fungus farming during periods of global warming. BMC Evol. Biol. 2012, 12, 133. [CrossRef] [PubMed]

58. Maner, M.L.; Hanula, J.L.; Braman, S.K. Gallery productivity, emergence, and flight activity of the redbay ambrosia beetle (Coleoptera: Curculionidae: Scolytinae). Environ. Entomol. 2013, 42, 642-647. [CrossRef] [PubMed]

59. Farrell, B.D.; Sequeira, A.; O’Meara, B.; Normark, B.B.; Chung, J.; Jordal, B. The evolution of agriculture in beetles (Curculionidae: Scolytinae and Platypodinae). Evolution 2001, 55, 2011-2027. [CrossRef] [PubMed]

60. Six, D.L. Bark beetle-fungus symbioses. In Insect Symbiosis; Bourtzis, K., Miller, T., Eds.; CRC Press: Boca Raton, FL, USA, 2003; pp. 97-114.

61. Hulcr, J.; Stelinski, L.L. The ambrosia symbiosis: From evolutionary ecology to practical management. Annu. Rev. Entomol. 2017, 62, 285-303. [CrossRef] [PubMed]

62. Francke-Grosmann, H. Ectosymbiosis in wood-inhabiting insects. In Symbiosis (Volume 2-Associations of Invertebrates, Birds, Ruminants and Other Biota; Henry, S.M., Ed.; Academic Press: New York, NY, USA, 1967; pp. 141-206.

63. Hulcr, J.; Cognato, A.I. Repeated evolution of crop theft in fungus-farming ambrosia beetles. Evolution 2010, 64, 3205-3212. [CrossRef] [PubMed]

64. Ngoan, N.D.; Wilkinson, R.C.; Short, D.E.; Moses, C.S.; Mangold, J.R. Biology of an introduced ambrosia beetle, Xylosandrus compactus, in Florida. Ann. Entomol. Soc. Am. 1976, 69, 872-876. [CrossRef]

65. Ranger, C.M.; Reding, M.E.; Persad, A.B.; Herms, D.A. Ability of stress-related volatiles to attract and induce attacks by Xylosandrus germanus and other ambrosia beetles. Agric. For. Entomol. 2010, 12, 177-185. [CrossRef]

66. Kendra, P.E.; Montgomery, W.S.; Niogret, J.; Pruett, G.E.; Mayfield, A.E., III; MacKenzie, M.; Deyrup, M.A.; Bauchan, G.R.; Ploetz, R.C.; Epsky, N.D. North American Lauraceae: Terpenoid emissions, relative attraction 
and boring preferences of redbay ambrosia beetle, Xyleborus glabratus (Coleoptera: Curculionidae: Scolytinae). PLoS ONE 2014, 9, e102086. [CrossRef] [PubMed]

67. Kuhnholz, S.; Borden, J.H.; Uzunovic, A. Secondary ambrosia beetles in apparently healthy trees: Adaptions, potential causes and suggested research. Integr. Pest Manag. Rev. 2002, 6, 209-219. [CrossRef]

68. Hulcr, J.; Dunn, R.R. The sudden emergence of pathogenicity in insect-fungus symbioses threatens naive forest ecosystems. Proc. Roy. Soc. B Sci. 2011, 278, 2866-2873. [CrossRef] [PubMed]

69. Carrillo, D.; Duncan, R.E.; Ploetz, J.N.; Campbell, A.; Ploetz, R.C.; Peña, J.E. Lateral transfer of a phytopathogenic symbiont among native and exotic ambrosia beetles. Plant Pathol. 2014, 63, 54-62. [CrossRef]

70. Ploetz, R.C.; Konkol, J.L.; Narvaez, T.; Duncan, R.E.; Saucedo, R.J.; Campbell, A.; Mantilla, J.; Carrillo, D.; Kendra, P.E. Presence and prevalence of Raffaelea lauricola, cause of laurel wilt, in different species of ambrosia beetle in Florida USA. J. Econ. Entomol. 2017. [CrossRef] [PubMed]

71. Batra, L.R. Ambrosia fungi: Extent of specificity to ambrosia beetles. Science 1966, 173, 193-195. [CrossRef] [PubMed]

72. Harrington, T.C. Ecology and evolution of mycophagous bark beetles and their fungal partners. In Insect-Fungal Associations. Ecology and Evolution; Vega, F.E., Blackwell, M., Eds.; Oxford University Press: New York, NY, USA, 2005; pp. 257-291.

73. Gebhardt, H.; Begerow, D.; Oberwinkler, F. Identification of the ambrosia fungus of Xyleborus monographus and X. dryographus (Coleoptera: Curculionidae, Scolytinae). Mycol. Prog. 2004, 3, 95-102. [CrossRef]

74. Kostovcik, M.; Bateman, C.C.; Kolarik, M.; Stelinski, L.L.; Jordal, B.H.; Hulcr, J. The ambrosia symbiosis is specific in some species and promiscuous in others: Evidence from community pyrosequencing. ISME J. 2015, 9, 126-138. [CrossRef] [PubMed]

75. Harrington, T.C.; Aghayeva, D.N.; Fraedrich, S.W. New combinations in Raffaelea, Ambrosiella, and Hyalorhinocladiela, and four new species from the redbay ambrosia beetle, Xyleborus glabratus. Mycotaxon 2010, 111, 337-361. [CrossRef]

76. Harrington, T.C.; Fraedrich, S.W. Quantification of propagules of the laurel wilt fungus and other mycangial fungi from the redbay ambrosia beetle, Xyleborus glabratus. Phytopathology 2010, 100, 1118-1123. [CrossRef] [PubMed]

77. Hulcr, J.; Mann, R.; Stelinski, L.L. The scent of a partner: Ambrosia beetles are attracted to volatiles from their fungal symbionts. J. Chem. Ecol. 2011, 37, 1374-1377. [CrossRef] [PubMed]

78. Hanula, J.L.; Mayfield, A.E., III; Fraedrich, S.W.; Rabaglia, R.J. Biology and host associations of redbay ambrosia beetle (Coleoptera: Curculionidae: Scolytinae), exotic vector of laurel wilt killing redbay trees in the southeastern United States. J. Econ. Entomol. 2008, 101, 1276-1286. [CrossRef] [PubMed]

79. Miller, D.R.; Rabaglia, R.J. Ethanol and (-)- $\alpha$-pinene: Attractant kairomones for bark and ambrosia beetles in the southeastern U.S. J. Chem. Ecol. 2009, 35, 435-448. [CrossRef] [PubMed]

80. Hanula, J.L.; Sullivan, B. Manuka oil and phoebe oil are attractive baits for Xyleborus glabratus (Coleoptera: Curculionidae: Scolytinae), the vector of laurel wilt. Environ. Entomol. 2008, 37, 1403-1409. [CrossRef] [PubMed]

81. Kendra, P.E.; Montgomery, W.S.; Niogret, J.; Peña, J.E.; Capinera, J.L.; Brar, G.; Epsky, N.D.; Heath, R.R. Attraction of the redbay ambrosia beetle, Xyleborus glabratus, to avocado, lychee, and essential oil lures. J. Chem. Ecol. 2011, 37, 932-942. [CrossRef] [PubMed]

82. Niogret, J.; Kendra, P.E.; Epsky, N.D.; Heath, R.R. Comparative analysis of terpenoid emissions from Florida host trees of the redbay ambrosia beetle, Xyleborus glabratus (Coleoptera: Curculionidae: Scolytinae). Fla. Entomol. 2011, 94, 1010-1017. [CrossRef]

83. Hanula, J.L.; Sullivan, B.T.; Wakarchuk, D. Variation in manuka oil lure efficacy for capturing Xyleborus glabratus (Coleoptera: Curculionidae: Scolytinae), and cubeb oil as an alternative attractant. Environ. Entomol. 2013, 42, 333-340. [CrossRef] [PubMed]

84. Kendra, P.E.; Montgomery, W.S.; Niogret, J.; Epsky, N.D. An uncertain future for American Lauraceae: A lethal threat from redbay ambrosia beetle and laurel wilt disease. Amer. J. Plant Sci. 2013, 4, 727-738. [CrossRef]

85. Kendra, P.E.; Montgomery, W.S.; Niogret, J.; Schnell, E.Q.; Deyrup, M.A.; Epsky, N.D. Evaluation of seven essential oils identifies cubeb oil as most effective attractant for detection of Xyleborus glabratus. J. Pest Sci. 2014, 87, 681-689. [CrossRef] 
86. Kendra, P.E.; Niogret, J.; Montgomery, W.S.; Deyrup, M.A.; Epsky, N.D. Cubeb oil lures: Terpenoid emissions, trapping efficacy, and longevity for attraction of redbay ambrosia beetle (Coleoptera: Curculionidae: Scolytinae). J. Econ. Entomol. 2015, 108, 350-361. [CrossRef] [PubMed]

87. Kendra, P.E.; Montgomery, W.S.; Deyrup, M.A.; Wakarchuk, D. Improved lure for redbay ambrosia beetle developed by enrichment of $\alpha$-copaene content. J. Pest Sci. 2016, 89, 427-438. [CrossRef]

88. Kendra, P.E.; Montgomery, W.S.; Schnell, E.Q.; Deyrup, M.A.; Epsky, N.D. Efficacy of $\alpha$-copaene, cubeb, and eucalyptol lures for detection of redbay ambrosia beetle (Coleoptera: Curculionidae: Scolytinae). J. Econ. Entomol. 2016, 109, 2428-2435. [CrossRef] [PubMed]

89. Chen, H.; Li, Z.; Tang, M. Laboratory evaluation of flight activity of Dendroctonus armando (Coleoptera: Curculionidae: Scolytinae). Canad. Entomol. 2010, 142, 378-387. [CrossRef]

90. Kendra, P.E.; Montgomery, W.S.; Niogret, J.; Deyrup, M.A.; Guillén, L.; Epsky, N.D. Xyleborus glabratus, $X$. affinis, and X. ferrugineus (Coleoptera: Curculionidae: Scolytinae): Electroantennogram responses to host-based attractants and temporal patterns in host-seeking flight. Environ. Entomol. 2012, 41, 1597-1605. [CrossRef] [PubMed]

91. Kuhns, E.H.; Martini, X.; Tribuiani, Y.; Coy, M.; Gibbard, C.; Peña, J.; Hulcr, J.; Stelinski, L.L. Eucalyptol is an attractant of the redbay ambrosia beetle, Xyleborus glabratus. J. Chem. Ecol. 2014, 40, 355-362. [CrossRef] [PubMed]

92. Martini, X.; Hughes, M.A.; Smith, J.A.; Stelinski, L.L. Attraction of redbay ambrosia beetle, Xyleborus glabratus, to leaf volatiles of its host plants in North America. J. Chem. Ecol. 2015, 41, 613-621. [CrossRef] [PubMed]

93. Mayfield, A.E., III; Brownie, C. The redbay ambrosia beetle (Coleoptera: Curculionidae: Scolytinae) uses stem silhouette diameter as a visual host-finding cue. Environ. Entomol. 2013, 42, 743-750. [CrossRef] [PubMed]

94. Niogret, J.; Epsky, N.D.; Schnell, R.J.; Boza, E.J.; Kendra, P.E.; Heath, R.R. Terpenoid variations within and among half-sibling avocado trees, Persea americana Mill. (Lauraceae). PLoS ONE 2013, 8, e73601. [CrossRef] [PubMed]

95. Maner, M.L.; Hanula, J.L.; Horn, S. Population trends of the redbay ambrosia beetle (Coleoptera: Curculionidae: Scolytinae): Does utilization of small diameter redbay trees allow populations to persist? Fla. Entomol. 2014, 97, 208-216. [CrossRef]

96. Kuhns, E.H.; Tribuiani, Y.; Martini, X.; Meyer, W.L.; Peña, J.; Hulcr, J.; Stelinski, L.L. Volatiles from the symbiotic fungus Raffaelea lauricola are synergistic with manuka lures for increased capture of the redbay ambrosia beetle Xyleborus glabratus. Agric. For. Entomol. 2014, 16, 87-94. [CrossRef]

97. Kim, K.-H.; Choi, Y.J.; Seo, S.-T.; Shin, H.-D. Raffaelea quercus-mongolicae sp. nov. associated with Platypus koryoensis on oak in Korea. Mycotaxon 2009, 110, 189-197. [CrossRef]

98. Matsuda, Y.; Kimura, K.; Ito, S.-I. Genetic characterization of Raffaelea quercivora isolates collected from areas of oak wilt in Japan. Mycoscience 2010, 51, 310-316. [CrossRef]

99. Six, D.L.; Wingfield, M.J. The role of phytopathogenicity in bark beetle-fungus symbioses: A challenge to the classic paradigm. Annu. Rev. Entomol. 2011, 56, 255-272. [CrossRef] [PubMed]

100. Rollins, J.A.; Ploetz, R.C.; Zhang, Y. Genomic insights into the mechanisms of pathogenesis in Raffaelea lauricola, causal agent of laurel wilt disease. University of Florida: Gainesville, FL, USA, Unpublished data. 2017.

101. Dreaden, T.J.; Davis, J.M.; de Beer, W.Z.; Ploetz, R.C.; Soltis, P.S.; Wingfield, M.J.; Smith, J.A. Phylogeny of ambrosia beetle symbionts in the genus Raffaelea. Fungal Biol. 2014. [CrossRef] [PubMed]

102. Simmons, D.R.; de Beer, Z.W.; Huang, Y.-T.; Bateman, C.C.; Campbell, A.; Dreaden, T.J.; Li, Y.; Ploetz, R.C.; Li, H.-F.; Chen, C.-Y.; et al. New Raffaelea species (Ophiostomataceae) from the United States and Taiwan associated with ambrosia beetles and plant hosts. IMA Fungus 2016, 7, 265-273. [PubMed]

103. Dreaden, T.J.; Campbell, A.S.; Gonzalez-Benecke, C.A.; Ploetz, R.C.; Smith, J.A. Response of swamp bay, Persea palustris, and redbay, P. borbonia, to Raffaelea spp. isolated from Xyleborus glabratus. For. Pathol. 2016. [CrossRef]

104. Chanderbali, A.S.; van der Werff, H.; Renner, S.S. Phylogeny and historical biogeography of Lauraceae: Evidence from the chloroplast and nuclear genomes. Ann. Missouri Bot. Garden 2001, 88, 104-134. [CrossRef]

105. Drinnan, A.; Crane, P.; Friis, E.; Pedersen, K. Lauraceous flowers form the Potomac Group (Mid-Cretaceous) of Eastern North America. Bot. Gaz. 1990, 151, 370-384. [CrossRef] 
106. Li, L.; Li, J.; Rohwer, J.G.; van der Werff, H.; Wang, Z.-H.; Li, H.-W. Molecular phylogenetic analysis of the Persea group (Lauraceae) and its biogeographic implications on the evolution of tropical and subtropical amphi-Pacific disjunctions. Am. J. Bot. 2011, 98, 1520-1536. [CrossRef] [PubMed]

107. Huang, J.-F.; Li, L.; van der Werff, H.; Li, H.-W.; Rohwer, J.G.; Crayn, D.M.; Meng, H.H.; van der Merwe, M.; Conran, J.G.; Li, J. Origins and evolution of cinnamon and camphor: A phylogenetic and historical biogeographical analysis of the Cinnamomum group (Lauraceae). Molec. Phylogenet. Evol. 2016, 96, $33-44$. [CrossRef] [PubMed]

108. Langeland, K.A.; Cherry, H.M.; McCormick, C.M.; Burks, K.A.C. Identification and Biology of Nonnative Plants in Florida's Natural Areas; IFAS Communication Services, University of Florida: Gainesville, FL, USA, 2008.

109. Schaffer, B.; Gil, P.M.; Mickelbart, M.V.; Whiley, A.W. Ecophysiology. In The Avocado: Botany, Production and Uses, 2nd ed.; Schaffer, B., Wolstenholme, B.N., Whiley, A.W., Eds.; CAB International Publishing: Wallingford, UK, 2013; pp. 168-199.

110. Gentry, A. Neotropical floristic diversity: Phytogeographical connections between Central and South America, Pleistocene climate fluctuations, or an accident of the Andean orogeny? Ann. Mo. Bot. Gard. 1982, 69, 557-593. [CrossRef]

111. Bosque, C.; Ramírez, R.; Rodríguez, D. The diet of the oilbird in Venezuela. Ornitol. Neotropical 1995, 6, 67-80.

112. Food and Agriculture Organization of the United Nations. FAOSTAT. Available online: http://www.fao. org/faostat/en/\#data (accessed on 21 December 2016).

113. Evans, E.A.; Current losses of avocado to laurel wilt. University of Florida, Homestead, FL, USA. Personal communication, 2017.

114. Podger, F.D. Phytophthora cinnamomi, a cause of lethal disease in indigenous plant communities in Western Australia. Phytopathology 1972, 62, 972-981. [CrossRef]

115. Lahav, E.; Lavi, U. Genetics and breeding. In The Avocado: Botany, Production and Uses, 2nd ed.; Schaffer, B., Wolstenholme, B.N., Whiley, A.W., Eds.; CAB International Publishing: Wallingford, UK, 2013; pp. 51-85.

116. Whiley, A.W.; Schaffer, B. Avocado. In Environmental Physiology of Fruit Crops, Vol. 2, Subtropical and Tropical Crops; Schaffer, B., Andersen, P.C., Eds.; CRC Press: Boca Raton, FL, USA, 1994; pp. 165-197.

117. Ploetz, R.C.; Pérez-Martínez, J.M.; Smith, J.A.; Hughes, M.; Dreaden, T.J.; Inch, S.A.; Fu, Y. Responses of avocado to laurel wilt, caused by Raffaelea lauricola. Plant Pathol. 2012, 61, 801-808. [CrossRef]

118. Ploetz, R.C.; Schaffer, B.; Vargas, A.I.; Konkol, J.L.; Salvatierra, J.; Wideman, R. Impact of laurel wilt, caused by Raffaelea lauricola, on leaf gas exchange and xylem sap flow in avocado, Persea americana. Phytopathology 2015, 105, 433-440. [CrossRef] [PubMed]

119. Ploetz, R.C.; Hughes, M.A. Susceptibility of gulf licaria and lancewood to laurel wilt. University of Florida: Homestead, FL, USA; University of Hawaii: Hilo, HI, USA, Unpublished data. 2017.

120. Hughes, M.A.; Smith, J.A. Vegetative propagation of putatively laurel wilt-resistant redbay (Persea borbonia). Native Plants 2014, 115, 42-50. [CrossRef]

121. Campbell, A.S.; Ploetz, R.C.; Rollins, J.A. Comparing avocado, swamp bay, and camphortree as hosts of Raffaelea lauricola using a green fluorescent protein (GFP)-labeled strain of the pathogen. Phytopathology 2016, 107, 70-74. [CrossRef] [PubMed]

122. Inch, S.A.; Ploetz, R.C. Impact of laurel wilt, caused by Raffaelea lauricola, on xylem function in avocado. Forest Pathol. 2012, 42, 239-245. [CrossRef]

123. Inch, S.A.; Ploetz, R.C.; Held, B.; Blanchette, R. Histological and anatomical responses in avocado, Persea americana, induced by the vascular wilt pathogen, Raffaelea lauricola. Botany 2012, 90, 627-635. [CrossRef]

124. Beckman, C.H. Host response to vascular infection. Annu. Rev. Phytopathol. 1964, 2, 231-252. [CrossRef]

125. Bonsen, K.J.M.; Kucera, L.J. Vessel occlusions in plants: morphological functional and evolutionary aspects. IAWA J. 1990, 11, 393-399. [CrossRef]

126. Bishop, C.D.; Cooper, R.M. Ultrastructure of vascular colonization by fungal wilt pathogens. II. Invasion of resistant cultivars. Physiol. Plant Pathol. 1984, 24, 277-289. [CrossRef]

127. Struckmeyer, B.E.; Beckman, C.H.; Kuntz, J.E.; Ricker, A.J. Plugging of vessels by tyloses and gums in wilting oaks. Phytopathology 1954, 44, 148-153.

128. Jacobi, W.R.; MacDonald, W.L. Colonization of resistant and susceptible oaks by Ceratocystis fagacearum. Phytopathology 1980, 70, 618-623. [CrossRef] 
129. Rioux, D.; Ouellette, G.B. Light microscope observations of histological changes induced by Ophiostoma ulmi in various nonhost trees and shrubs. Can. J. Bot. 1989, 67, 2335-2351. [CrossRef]

130. Fry, S.M.; Milholland, R.D. Response of resistant, tolerant, and susceptible grapevine tissues to invasion by pierce's disease bacterium, Xylella fastidiosa. Phytopathology 1990, 80, 66-69. [CrossRef]

131. Rioux, D.; Nicole, M.; Simard, M.; Ouellette, G.B. Immunocytochemical evidence that secretion of pectin occurs during gel (gum) and tylosis formation in trees. Phytopathology 1998, 88, 494-505. [CrossRef] [PubMed]

132. Collins, B.R.; Parke, J.L.; Lachenbruch, B.; Hansen, E.M. The effects of Phytophthora ramorum infection on hydralic conductivity and tylosis formation in tanoak sapwood. Can. J. For. Res. 2009, 39, 1766-1776. [CrossRef]

133. VanderMolen, G.E.; Beckman, C.H.; Rodehorst, E. Vascular gelation: A general response phenomenon following infection. Physiol. Plant Pathol. 1977, 11, 85-100. [CrossRef]

134. Aist, J.R. Structural responses as resistance mechanisms. In The dynamics of host defense; Bailey, J.A., Deverall, B.J., Eds.; Academic Press: Sydney, Australia, 1983; pp. 33-70.

135. Gagnon, C. Histochemical studies on the alteration of lignin and pectic substances in white elm infected by Ceratocystis ulmi. Can. J. Bot. 1967, 45, 1619-1623. [CrossRef]

136. Hughes, M.A.; Inch, S.A.; Ploetz, R.C.; Er, H.L.; van Bruggen, A.H.C.; Smith, J.A. Responses of swamp bay, Persea palustris, and avocado, Persea americana, to the laurel wilt pathogen, Raffaelea lauricola. For. Pathol. 2015, 45, 111-119. [CrossRef]

137. Urban, J.; Dvořák, M. Occlusion of sap flow in elm after artificial inoculation with Ophiostoma novo-ulmi. Acta Hort. 2013, 991, 301-306. [CrossRef]

138. Park, J.-H.; Juzwik, J.; Cavender-Bares, J. Multiple Ceratocystis smalleyi infections associated with reduced stem water transport in bitternut hickory. Phytopathology 2013, 103, 565-574. [CrossRef] [PubMed]

139. Murata, M.; Yamada, T.; Ito, S. Changes in water status in seedlings of six species in the Fagaceae after inoculation with Raffaelea quercivora Kubono et Shin-Ito. J. For. Res. 2005, 10, 251-255. [CrossRef]

140. Parke, J.L.; Oh, E.; Voelker, S.; Hansen, E.M.; Buckles, G.; Lachenbruch, B. Phytophthora ramorum colonizes tanoak xylem and is associated with reduced stem water transport. Phytopathology 2007, 97, 1558-1567. [CrossRef] [PubMed]

141. Li, Q.; Wang, X.X.; Lin, J.G.; Liu, J.; Jiang, M.S.; Chu, L.X. Chemical Composition and Antifungal Activity of Extracts from the Xylem of Cinnamomum camphora. BioResources 2014, 9, 2560-2571. [CrossRef]

142. Solla, A.; Gil, L. Xylem vessel diameter as a factor in resistance of Ulmus minor to Ophiostoma novo-ulmi. For. Pathol. 2002, 32, 123-134. [CrossRef]

143. Solla, A.; Martín, J.A.; Corral, P.; Gil, L. Seasonal changes in wood formation of Ulmus pumila and U. minor and its relation with Dutch elm disease. New Phytol. 2005, 166, 1025-1034. [CrossRef] [PubMed]

144. Venturas, M.; Lopez, R.; Martın, R.A.; Gasco, A.; Gil, L. Heritability of Ulmus minor resistance to Dutch elm disease and its relationship to vessel size, but not to xylem vulnerability to drought. Plant Pathol. 2014, 63, 500-509. [CrossRef]

145. Cameron, R.S.; Hanula, J.; Fraedrich, S.W.; Bates, C. Progression of laurel wilt disease within redbay and sassafras populations in southeast Georgia. Southeast Nat. 2015, 14, 650-674. [CrossRef]

146. Smith, C.K.; Landreaux, E.; Steinmann, H.; McGrath, D.; Hayes, C.; Hayes, R. Redbay survival eleven years after infection with an exotic disease on St. Catherines Island, Georgia, USA. Environ. Nat. Resour. Res. 2015, 6, 27-34. [CrossRef]

147. Cameron, R.S.; Bates, C.; Johnson, J. Progression of laurel wilt disease in Georgia: 2009-2011 (Project SC-EM-08-02). In Forest Health Monitoring: National Status, Trends and Analysis; Potter, K.M., Conlking, B.L., Eds.; Southern Research Station, USDA-ARS: Asheville, NC, USA, 2012; pp. 145-151.

148. Best, S.; Fraedrich, S. The impact of laurel wilt caused by Raffaelea lauricola on clonal populations of pondberry (Lindera melissifolia). Phytopathology 2016, 106, S4.124.

149. Beckman, F.C. Laurel Wilt: Assessing the Risk of Pruning Tool Transmission of Raffaelea lauricola. Master's Thesis, University of Florida, Gainesville, FL, USA, 2012.

150. Ploetz, R.C.; Inch, S.A.; Pérez-Martínez, J.M.; White, T.L., Jr. Systemic infection of avocado, Persea americana, by Raffaelea lauricola, does not progress into fruit pulp or seed. J. Phytopathol. 2012, 160, 491-495. [CrossRef]

151. Ploetz, R.C.; White, T.; Konkol, J. Raffaelea lauricola is not transmitted through scions of avocado that are used for grafting. University of Florida: Homestead, FL, USA, Unpublished data. 2017. 
152. Evans, E.A.; Ballen, F.H. An econonmetric demand model for Florida green-skin avocados. HortTechnology 2015, 25, 405-411.

153. Ploetz, R.C.; Peña, J.E.; Smith, J.A.; Dreaden, T.L.; Crane, J.H.; Schubert, T.; Dixon, W. Laurel wilt is confirmed in Miami-Dade County, center of Florida's commercial avocado production. Plant Dis. 2011, 95, 1599. [CrossRef]

154. Gottwald, T.R.; Hughes, G.; Graham, J.H.; Sun, X.; Riley, T. The citrus canker epidemic in Florida: The scientific basis of regulatory eradication policy for an invasive species. Phytopathology 2001, 91, 30-34. [CrossRef] [PubMed]

155. Gottwald, T.R.; Wierenga, E.; Luo, W.; Parnell, S. Epidemiology of Plum pox 'D'strain in Canada and the USA. Can. J. Plant Pathol. 2013, 35, 442-457. [CrossRef]

156. Drew, J.; Anderson, N.; Andow, D. Conundrums of a complex vector for invasive species control: A detailed examination of the horticultural industry. Biol. Invas. 2010, 12, 2837-2851. [CrossRef]

157. Fry, W.E.; McGrath, M.T.; Seaman, A.; Zitter, T.A.; McLeod, A.; Danies, G.; Gugino, B.K. The 2009 late blight pandemic in the eastern United States-Causes and results. Plant Dis. 2013, 97, 296-306. [CrossRef]

158. Brar, G.S.; Capinera, J.L.; Kendra, P.E.; McLean, S.; Peña, J.E. Life cycle, development, and culture of Xyleborus glabratus (Coleoptera: Curculionidae: Scolytinae). Fla. Entomol. 2013, 96, 1158-1167. [CrossRef]

159. Plantegenest, M.; Le May, C.; Fabre, F. Landscape epidemiology of plant diseases. J. R. Soc. Interface 2007, 4, 963-972. [CrossRef] [PubMed]

160. Carrillo, D.; Choudrey, R.; Garrett, K. Spatial distribution of laurel wilt outbreaks in commercial avocado production areas in south Florida suggest no connection with outbreaks of the disease in neighboring natural areas. University of Florida: Homestead, FL, USA, Unpublished data. 2017.

161. La Rue, C.D. Root grafting in trees. Am. J. Bot. 1934, 21, 121-126. [CrossRef]

162. La Rue, C.D. Root-grafting in tropical trees. Science 1952, 115, 296. [CrossRef] [PubMed]

163. Epstein, A.H. Root graft transmission of tree pathogens. Annu. Rev. Phytopathol. 1978, 16, 181-192. [CrossRef]

164. Himelick, E.B.; Neely, D. Root grafting of city-planted American elms. Plant Dis. Rep. 1962, 46, 86-87.

165. Sinclair, W.A.; Lyon, J. Diseases of Trees and Shrubs, 2nd ed.; Cornell University Press: Ithaca, NY, USA, 2005; pp. 1-680.

166. Horne, W.T.; Parker, E.R. The avocado disease called sunblotch. Phytopathology 1931, 21, 235-238.

167. Wallace, J.M.; Drake, R.J. A high rate of seed transmission of avocado sun blotch virus from symptomless trees and the origin of such trees. Phytopathology 1962, 52, 237-241.

168. Dann, E.; Ploetz, R.C.; Pegg, K.G.; Coates, L. Diseases of avocado. In The Avocado, 2nd ed.; Schaffer, B., Ed.; CABI: Wallingford, UK, 2012; pp. 380-422.

169. Ploetz, R.C.; Konkol, J. Herbicide treatment to establish barriers around laurel wilt affected avocado trees. University of Florida: Homestead, FL, USA, Unpublished data. 2017.

170. Koch, F.H.; Smith, W.D. Spatio-temporal analysis of Xyleborus glabratus (Coleoptera: Circulionidae: Scolytinae) invasion in eastern US forests. Environ. Entomol. 2008, 37, 442-452. [CrossRef] [PubMed]

171. Cameron, R.S.; Bates, C.; Johnson, J. Distribution and Spread of Laurel wilt Disease in Georgia: 2006-2008 Survey and Field Observations; Georgia Forestry Commission Report, 2006-2008; Georgia Forestry Commission: Tifton, GA, USA, 2008.

172. Riggins, J.J.; Hughes, M.; Smith, J.A.; Mayfield, A.E., III; Layton, B.; Balbalian, C.; Campbell, R. First occurrence of laurel wilt disease caused by Raffaelea lauricola on redbay trees in Mississippi. Plant Dis. 2010, 94, 634. [CrossRef]

173. Bates, C.A.; Fraedrich, S.W.; Harrington, T.C.; Cameron, R.S.; Menard, R.D.; Best, G.S. First report of laurel wilt, caused by Raffaelea lauricola, on sassafras (Sassafras albidum) in Alabama. Southeast Nat. 2015, 14, 650-674.

174. Fraedrich, S.W.; Johnson, C.W.; Menard, R.D.; Harrington, T.C.; Olatinwo, R.; Best, G.S. First report of Xyleborus glabratus (Coleoptera: Curculionidae: Scolytinae) and laurel wilt in Louisiana, USA: The disease continues westward on sassafras. Fla. Entomol. 2015, 98, 1266-1268. [CrossRef]

175. Olatinwo, R.; Barton, C.; Fraedrich, S.W.; Johnson, W.; Hwang, J. First report of laurel wilt, caused by Raffaelea lauricola, on sassafras (Sassafras albidum) in Arkansas. Plant Dis. 2016, 100, 2331. [CrossRef]

176. Shearman, T.M.; Wang, G.G.; Bridges, W.C. Population dynamics of redbay (Persea borbonia) after laurel wilt disease: An assessment based on forest inventory and analysis data. Biol. Invasions 2015, 17, 1371-1382. [CrossRef] 
177. Moslonka-Lefebvre, M.; Finley, A.; Dorigatti, I.; Dehnen-Schmutz, K.; Harwood, T.; Jeger, M.J.; Xu, X.M.; Holdenrieder, O.; Pautasso, M. Networks in plant epidemiology: From genes to landscapes, countries, and continents. Phytopathology 2011, 101, 392-403. [CrossRef] [PubMed]

178. Shaw, M.W.; Pautasso, M. Networks and plant disease management: Concepts and applications. Annu. Rev. Phytopathol. 2014, 52, 477-493. [CrossRef] [PubMed]

179. Harwood, T.D.; Xu, X.; Pautasso, M.; Jeger, M.J.; Shaw, M.W. Epidemiological risk assessment using linked network and grid based modelling: Phytophthora ramorum and Phytophthora kernoviae in the UK. Ecol. Model. 2009, 220, 3353-3361. [CrossRef]

180. Nopsa, J.F.H.; Daglish, G.J.; Hagstrum, D.W.; Leslie, J.F.; Phillips, T.W.; Scoglio, C.; Thomas-Sharma, S.; Walter, G.H.; Garrett, K.A. Ecological networks in stored grain: Key postharvest nodes for emerging pests, pathogens, and mycotoxins. Bioscience 2015, 65, 985-1002. [CrossRef] [PubMed]

181. Sutrave, S.; Scoglio, C.; Isard, S.A.; Hutchinson, J.M.S.; Garrett, K.A. Identifying highly connected counties compensates for resource limitations when evaluating national spread of an invasive pathogen. PLoS ONE 2012, 7, e37793. [CrossRef] [PubMed]

182. Garrett, K.A. Impact Network Analysis: A framework for evaluating the effects of information and other technologies through linked socioeconomic and biophysical networks. bioRxiv 2017, in press.

183. Grimm, V.; Revilla, E.; Berger, U.; Jeltsch, F.; Mooij, W.M.; Railsback, S.F.; Thulke, H.H.; Weiner, J.; Wiegand, T.; DeAngelis, D.L. Pattern-oriented modeling of agent-based complex systems: Lessons from ecology. Science 2005, 310, 987-991. [CrossRef] [PubMed]

184. Garrett, K.A. Information networks for plant disease: Commonalities in human management networks and within-plant signaling networks. Eur. J. Plant Pathol. 2012, 133, 75-88. [CrossRef]

185. Mills, P.; Dehnen-Schmutz, K.; Ilbery, B.; Jeger, M.; Jones, G.; Little, R.; MacLeod, A.; Parker, S.; Pautasso, M.; Pietravalle, S.; et al. Integrating natural and social science perspectives on plant disease risk, management and policy formulation. Philos. Trans. R. Soc. B Biol. Sci. 2011, 366, 2035-2044. [CrossRef] [PubMed]

186. Rebaudo, F.; Dangles, O. Coupled information diffusion-pest dynamics models predict delayed benefits of farmer cooperation in pest management programs. PLoS Comput. Biol. 2011, 7, e1002222. [CrossRef] [PubMed]

187. McRoberts, N.; Hall, C.; Madden, L.V.; Hughes, G. Perceptions of disease risk: From social construction of subjective judgments to rational decision making. Phytopathology 2011, 101, 654-665. [CrossRef] [PubMed]

188. Borer, E.; Laine, A.-L.; Seabloom, E. A multiscale approach to plant disease using the metacommunity concept. Annu. Rev. Phytopathol. 2016, 54, 397-418. [CrossRef] [PubMed]

189. Dreaden, T.J.; Davis, J.M.; Harmon, C.L.; Ploetz, R.C.; Palmateer, A.J.; Soltis, P.S.; Smith, J.A. Development of multilocus PCR assays for Raffaelea lauricola, causal agent of laurel wilt disease. Plant Dis. 2014, 98, 379-383. [CrossRef]

190. Sankaran, S.; Ehsani, R.; Inch, S.A.; Ploetz, R.C. Evaluation of visible-near infrared reflectance spectra of avocado leaves as a non-destructive sensing tool for detection of vascular infection by the laurel wilt pathogen, Raffaelea lauricola. Plant Dis. 2012, 96, 1683-1689. [CrossRef]

191. De Castro, A.I.; Ehsani, R.; Ploetz, R.; Crane, J.H.; Abdulridh, J. Optimum spectral and geometric parameters for early detection of laurel wilt disease in avocado. Rem. Sens. Environ. 2015, 171, 33-44. [CrossRef]

192. De Castro, A.I.; Ehsani, R.; Ploetz, R.C.; Crane, J.H.; Buchanon, S. Detection of laurel wilt disease in avocado using low altitude aerial imaging. PLoS ONE 2015, 10, e0124642. [CrossRef] [PubMed]

193. Pero, J. Bug off my guacamole. Mech. Engin.-CIME 2015, 137, 96-97.

194. Angle, C.; Waggoner, L.P.; Ferrando, A.; Haney, P.; Passler, T. Canine detection of the volatilome: A review of implications for pathogen and disease detection. Front. Vet. Sci. 2016, 3, 47. [CrossRef] [PubMed]

195. Mills, D. The Science of Laurel Wilt Canine Detection; Seminar Series; Tropical Research \& Education Center, University of Florida: Homestead, FL, USA, 2017.

196. Adkins, J. Canines Detect Deadly Disease in Historic Avocado Trees. Available online: https://news.fiu.edu/ 2015/10/canines-detect-deadly-disease-in-historic-avocado-trees/92863 (accessed on 31 January 2017).

197. Campbell, A.S.; Ploetz, R.C.; Kendra, P.E.; Montgomery, W.S.; Dreaden, T.J. Geographic variation in mycangial communities of Xyleborus glabratus. Mycologia 2016, 108, 657-667. [CrossRef] [PubMed]

198. An, L. Modeling human decisions in coupled human and natural systems: review of agent-based models. Ecol. Model. 2012, 229, 25-36. [CrossRef] 
199. Ploetz, R.C.; Konkol, J.L.; Pérez-Martínez, J.M.; Fernandez, R. Management of laurel wilt of avocado, caused by Raffaelea lauricola. Eur. J. Plant Pathol. 2017. [CrossRef]

200. Mayfield, A.E., III; Barnard, E.L.; Smith, J.A.; Bernick, S.C.; Eickwort, J.M.; Dreaden, T.J. Effect of propiconazole on laurel wilt disease development in redbay trees and on the pathogen in vitro. Arboric. Urban For. 2008, 34, 317-324.

(c)

(C) 2017 by the authors; licensee MDPI, Basel, Switzerland. This article is an open access article distributed under the terms and conditions of the Creative Commons Attribution (CC BY) license (http:/ / creativecommons.org/licenses/by/4.0/). 